\title{
Modeling dust sources, transport, and radiative effects at different altitudes over the Tibetan Plateau
}

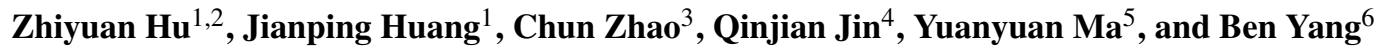 \\ ${ }^{1}$ Key Laboratory for Semi-Arid Climate Change of the Ministry of Education, College of Atmospheric Sciences, \\ Lanzhou University, Lanzhou, China \\ ${ }^{2}$ School of Atmospheric Sciences and Guangdong Province Key Laboratory for Climate Change and Natural Disaster Studies, \\ Sun Yat-sen University, Zhuhai, China \\ ${ }^{3}$ School of Earth and Space Sciences, University of Science and Technology of China, Hefei, Anhui, China \\ ${ }^{4}$ Department of Geography and Atmospheric Science, The University of Kansas, Lawrence, KS, USA \\ ${ }^{5}$ Key Laboratory of Land Surface Process and Climate Change in Cold and Arid Regions, \\ Northwest Institute of Eco-Environment and Resources, Chinese Academy of Sciences, Lanzhou, China \\ ${ }^{6}$ School of Atmospheric Sciences, Nanjing University, Nanjing, China
}

Correspondence: Jianping Huang (hjp@1zu.edu.cn)

Received: 6 May 2019 - Discussion started: 7 August 2019

Revised: 29 November 2019 - Accepted: 21 December 2019 - Published: 7 February 2020

\begin{abstract}
Mineral dust plays an important role in the climate of the Tibetan Plateau (TP) by modifying the radiation budget, cloud macro- and microphysics, precipitation, and snow albedo. Meanwhile, the TP, with the highest topography in the world, can affect intercontinental transport of dust plumes and induce typical distribution characteristics of dust at different altitudes. In this study, we conduct a quasi-global simulation to investigate the characteristics of dust source contribution and transport over the TP at different altitudes by using a fully coupled meteorology-chemistry model, the Weather Research and Forecasting model with chemistry (WRF-Chem), with a tracer-tagging technique. Generally, the simulation reasonably captures the spatial distribution of satellite-retrieved dust aerosol optical depth (AOD) at different altitudes. Model results show that dust particles are emitted into atmosphere through updrafts over major desert regions and then transported to the TP. The East Asian dust (mainly from the Gobi and Taklamakan deserts) is transported southward and is lifted up to the TP, contributing a mass loading of $50 \mathrm{mg} \mathrm{m}^{-2}$ at a height of $3 \mathrm{~km}$ and $5 \mathrm{mg} \mathrm{m}^{-2}$ at a height of $12 \mathrm{~km}$ over the northern slope of the TP. Dust from North Africa and the Middle East are concentrated over both of the northern and southern slopes below $6 \mathrm{~km}$, where mass loadings range from 10 to 100 and 1 to $10 \mathrm{mg} \mathrm{m}^{-2}$ below $3 \mathrm{~km}$ and above $9 \mathrm{~km}$, respectively. As the dust is trans-
\end{abstract}

ported to the north and over the TP, mass loadings are 5$10 \mathrm{mg} \mathrm{m}^{-2}$ above a height of $6 \mathrm{~km}$.

The dust mass flux carried from East Asia to the TP is $7.9 \mathrm{Tg} \mathrm{yr}^{-1}$, mostly occurring at heights of $3-6 \mathrm{~km}$. The dust particles from North Africa and the Middle East are transported eastward following the westerly jet and then are carried into the $\mathrm{TP}$ at the west side with dust mass fluxes of 7.8 and $26.6 \mathrm{Tg} \mathrm{yr}^{-1}$, respectively. The maximum mass flux of the North African dust mainly occurs at $0-3 \mathrm{~km}$ (3.9 $\mathrm{Tg} \mathrm{yr}^{-1}$ ), while the Middle Eastern dust occurs at 6$9 \mathrm{~km}\left(12.3 \mathrm{Tg} \mathrm{yr}^{-1}\right)$. The dust outflow occurs on the east side $\left(-17.89 \mathrm{Tg} \mathrm{yr}^{-1}\right)$ and south side $\left(-11.22 \mathrm{Tg} \mathrm{yr}^{-1}\right)$ of the TP, with a peak value $\left(8.7 \mathrm{Tg} \mathrm{yr}^{-1}\right)$ at $6-9 \mathrm{~km}$. Moreover, the dust (by mass) is concentrated within the size range of $1.25-5.0 \mu \mathrm{m}$ and the dust (by particle number) is concentrated in the size range of $0.156-1.25 \mu \mathrm{m}$. Compared with other aerosols, the dust contributes to more than $50 \%$ of the total AOD over the TP. The direct radiative forcing induced by the dust is $-1.28 \mathrm{~W} \mathrm{~m}^{-2}$ at the top of the atmosphere (cooling), $0.41 \mathrm{~W} \mathrm{~m}^{-2}$ in the atmosphere (warming), and $-1.68 \mathrm{~W} \mathrm{~m}^{-2}$ at the surface (cooling). Our quantitative analyses of the dust contributions from different source regions and the associated radiative forcing can help us to better understand the role of dust on the climate over the TP and surrounding regions. 


\section{Introduction}

Mineral dust, emitted from deserts such as the Sahara, Arabian, Gobi, and Taklamakan, is a major contributor to the global aerosol burden (e.g., Uno et al., 2009; Yu et al., 2012; Hu et al., 2016; Chen et al., 2018). Dust aerosols can be lifted into the upper troposphere by the strong frontal/postfrontal convection from major desert source regions and then transported to downwind regions following the westerlies (Zhao et al., 2006; Hu et al., 2019a, b), with parts of the dust even being transported for one full circuit around the globe (Uno et al., 2009). During the intercontinental transport, dust has a significant effect on the regional and global climate system (Lau et al., 2006; Jin et al., 2015; Pu and Ginoux, 2018; Chen et al., 2018). For instance, previous studies showed that dust could change the atmospheric heating and affect atmospheric circulation patterns in the middle and upper troposphere (Lau et al., 2006; Lau and Kim, 2006; Alizadeh-Choobari et al., 2014). Further, dust could spur anomalous water cycle feedback and alter the rainfall distribution over East Asia (Lau et al., 2016; Liu et al., 2011) and South Asia (Lau and Kim, 2006; Kim et al., 2017; Jin et al., 2014; Jin and Wang, 2017). Dust particles were also found to change regional radiation budget (Huang et al., 2005, 2006; Zhao et al., 2014; Bi et al., 2017) by scattering and absorbing the solar radiation and modifying the properties of clouds ( $\mathrm{Li}$ et al., 2017, 2018) by serving as cloud condensation nuclei and ice nuclei. Dust aerosols also exacerbate air quality (Chin et al., 2007; $\mathrm{Hu}$ et al., 2016) and reduce regional visibility (Watson, 2002). When deposited on the surface of snow/ice, dust could accelerate the snowmelt and glacier retreat and change the hydrological cycle (Qian et al., 2009; Painter et al., 2010; Huang et al., 2011; Zhao et al., 2014); when deposited into rainforests and oceans, dust could provide nutrients to ecosystems and influence the carbon cycle (Mahowald et al., 2008; Yu et al., 2015).

As the highest plateau (average elevation of about $4000 \mathrm{~m}$ ) in the world, the Tibetan Plateau (TP) has received extensive scientific attention in the past decades due to its unique topographic characteristics (Ma et al., 2014; Yao et al., 2012). The TP exerts profound influences on the climate system in the Northern Hemisphere by modulating the thermodynamics of the atmosphere (Yeh et al., 1957; Ye and Wu, 1998; Wu et al., 2007). Generally, the TP serves as a huge heat source in the middle and upper troposphere that significantly affects the Asian summer monsoon, while in winter the TP, as a giant wall across the Eurasian continent, can block cold outbreaks from the north and confines the winter monsoon to eastern and southern Asia (Wu et al., 2012). Recent studies have indicated that the climate of the TP is warming rapidly (e.g., Duan and Wu, 2008; Wang et al., 2008; Xu et al., 2009; Kang et al., 2010) and the glacier retreat is accelerating (Yao et al., 2007). These changes over the TP are primarily attributed to increasing greenhouse gases (e.g., Duan et al., 2006; Ren et al., 2006), but other major factors could also contribute to these changes, such as absorbing aerosols (e.g., dust and black carbon), which can heat the atmosphere and reduce the snow albedo (Kang et al., 2000; Lau et al., 2006, 2010; Xu et al., 2009). The intercontinental transport of dust aerosols originating from surrounding major deserts, i.e., the Gobi and Taklamakan deserts on the northern side and Sahara and Arabian deserts on the western side, frequently assaults the TP (Huang et al., 2008; Liu et al., 2008) and greatly influences the regional climate over the TP (Lau et al., 2006; Wu et al., 2007). Meanwhile, the TP plays an important role in the global-scale transport of dust through dynamical and thermal forcing in the mid-latitudes (Xu et al., 2018). When dust plumes arrive at the TP, they are split into two branches and stack up around the slopes of the TP (Lau et al., 2006; Jin et al., 2016; Hu et al., 2019a); then dust particles rise to the TP due to the topographic uplifting. Because of a strong ability to absorb and scatter solar radiation, dust can heat up the air in the mid-to-upper troposphere (Lau et al., 2006; Lau and Kim, 2006; Nigam and Bollasina, 2010; D'Errico et al., 2015), which provides cyclonic conditions in the lower layer and induces dry convention over the TP (Ma et al., 2011; Xu et al., 2018). Under these conditions, dust particles can be more easily elevated into the upper troposphere and lower stratosphere and then continue the long-range transport with a relatively longer lifetime in the upper troposphere and lower stratosphere (Huang et al., 2008; Xu et al., 2018). Also, because of the rising of hot air induced by absorbing aerosols (e.g., dust or black carbon) over the TP, more warm and moist air is drawn into the Indian subcontinent, leading to an earlier onset of the South Asian summer monsoon and an intensification of the summer rainfall over the Indian subcontinent (Lau et al., 2006).

Although the long-range transport dust aerosols play an essential role in a rapid climate change over the TP, the characteristics of vertical distribution of dust are not well studied and are crucial to understanding the intercontinental transport of dust (Bourgeois et al., 2015; Xu et al., 2018). Using the Cloud-Aerosol Lidar and Infrared Pathfinder Satellite Observation (CALIPSO) retrievals, Xu et al. (2018) showed that the dust particles were uplifted to the middle troposphere over the source region and then transported eastward. When the dust particles reached the TP, they were lifted up to the upper troposphere, with a dust mass flux of about $10^{10} \mathrm{~g}$ integrated across a $2^{\circ}$-latitude segment, by the dry and deep convections that were prevailing in spring. Chen et al. (2013) addressed a dust storm that occurred in the Taklimakan Desert during 26-30 July 2007. They pointed out that a value of $6.6 \mathrm{Gg} \mathrm{d}^{-1}$ mass flux was brought into the TP and -5.58 , 1.61 , and $-3.97 \mathrm{~W} \mathrm{~m}^{-2}$ of dust radiative forcing were produced at the surface, in the atmosphere and at the top of the atmosphere (TOA), respectively. However, we are not aware of studies of the dust source contributions at different altitudes over the TP.

In general, many studies focused on dust events over the TP (Uno et al., 2004; Huang et al., 2007, 2008; Yumimoto et 
al., 2009, 2010; Chen et al., 2013). They showed that the dust could make an important impact on aerosol mass loading throughout the year, with the largest efficiency in spring and summer (Uno et al., 2004; Huang et al., 2007, 2008; Chen et al., 2013). For example, Middleton (1986) showed that the dust coupled with locally generated pollution aerosols from the Arabian Peninsula and Indian subcontinent was transported and loaded into the TP over the southern slope. The strength of the North African and Arabian Peninsula dust had a significantly seasonal variability, and it was observed to peak in summer (Liu et al., 2008; Alizadeh-Choobari et al., 2014; Jin et al., 2016). Huang et al. (2007) indicated that dust plumes originating from the nearby Taklimakan desert were lifted to a very high altitude $(7-10 \mathrm{~km})$ over the northern slope. Chen et al. (2017) pointed out that a dust storm occurring in 18-23 March 2010 brought dust aerosols from the Taklimakan Desert dust (up to $0.8 \mathrm{td}^{-1}$ ) and the Gobi Desert (up to $3.7 \mathrm{td}^{-1}$ ) into the TP. So far, however, few studies have described the dust plumes transported into the TP from a climatological view. Moreover, although the global-scale transport of dust has been studied using both observations and model simulations, the spatiotemporal characteristics of dust particle size and number and their associated climatic impact are poorly understood (Zhao et al., 2013b). The dust particle number could be used to determine the number of cloud condensation nuclei and/or ice nuclei (e.g., Liu and Penner, 2005; DeMott et al., 2010) and dust particle deposition (Zhao et al., 2013b). Consequently, this could affect the precipitation by modifying the cloud formation and distribution over the TP (Huang et al., 2014; Li et al., 2016) and further change the hydrological cycle, influencing the lives of people in South and East Asia (Xu et al., 2009; Yao et al., 2012).

In this study, we implement a newly developed tracertagging method in the Weather Research and Forecasting model with chemistry (WRF-Chem) to characterize the intercontinental transports of dust emitted from different major desert sources and quantify their contributions to the total dust mass loading over the TP (Wang et al., 2014; Hu et al., 2016, 2019a). A 6-year (2010-2015) quasi-global simulation is conducted in the updated version of WRF-Chem. Hu et al. (2016; 2019a, b) have shown that model results could represent the dust intercontinental transport over East Asia and the Pacific Ocean well when compared with multiple observations. Here, our purposes are to (1) explore the transport characteristics of dust particles from different major deserts at different altitudes over the TP, (2) describe the dust particle size distributions at different altitudes over the TP, (3) analyze the dust radiative forcing over the TP, and (4) compare dust mass and particle number concentrations with other aerosols at different altitudes over the TP.

The model setup and satellite retrievals will be described in Sects. 2 and 3, respectively. In Sect. 4, we will evaluate the simulated dust aerosol optical depth (AOD) from WRFChem at different altitudes over the TP against satellite obser- vations. In Sect. 5, the main results will be presented, including the transport characteristics of dust from different source regions, the contribution of different major deserts to the dust mass and number of particles at different altitudes over the $\mathrm{TP}$, the dust mass flux carried into and flowing out from the $\mathrm{TP}$, and the dust radiative forcing. The conclusion is summarized in Sect. 6.

\section{Model}

\subsection{WRF-Chem}

In this study, the WRF-Chem model is updated at the University of Science and Technology of China (USTC) based on version 3.5.1 (Zhao et al., 2013b, 2014; Hu et al., 2016), including, particularly, the capability of quasi-global simulation and tracer source tagging (Hu et al., 2019a, b). It incorporates the Model for Simulation Aerosol Interactions and Chemistry (MOSAIC) aerosol scheme (Zaveri et al., 2008) and the Carbon Bond Mechanism (CBM-Z) photochemical mechanism (Zaveri and Peters, 1999) for simulating the complex photolysis rates and aerosol radiative properties (Fast et al., 2006). Eight size bins are used in the MOSAIC aerosol scheme to describe the aerosol size distributions using the bin approach (Fast et al., 2006), which could better represent the spatial distribution of the dust particles and dust size loading than 3-mode and 4-bin approaches (Zhao et al., 2013b). Meanwhile, all major aerosol components including mineral dust, sulfate $\left(\mathrm{SO}_{4}^{-2}\right)$, ammonium $\left(\mathrm{NH}_{4}^{+}\right)$, nitrate $\left(\mathrm{NO}_{3}^{-}\right)$, organic matter $(\mathrm{OM})$, black carbon $(\mathrm{BC})$, and sea salt are simulated in the model to represent the sophisticated chemistry during the long-range transport. The aerosol physical and chemical processes in MOSAIC include coagulation, condensation, nucleation, water uptake, and aqueousphase chemistry. The aerosol dry deposition approach including gravitational settling and turbulent diffusion follows Binkowski and Shankar (1995). Wet removal of aerosols induced by grid precipitation and resolved stratiform clouds is simulated using the approach of Easter et al. (2004) and Chapman et al. (2009). A function depending on wavelength is used for the aerosol optical properties of each model's grid box. The aerosol longwave (LW) and shortwave (SW) refractive indices use the Optical Properties of Aerosols and Clouds (OPAC) dataset, except for the SW refractive index of dust, which is defined as $1.53+0.003 i$, following Zhao et al. (2010, 2011). Zhao et al. (2013a) implemented the aerosol radiative feedback for LW and SW radiation into WRF-Chem, which had been coupled with the Rapid Radiative Transfer Model (RRTMG) (Mlawer et al., 1997; Iacono et al., 2000).

\subsection{Dust emission}

The dust emissions are simulated by the Goddard Chemistry Aerosol Radiation and Transport (GOCART) model (Ginoux 
et al., 2001), which has been fully coupled with the MOSAIC in WRF-Chem (Zhao et al., 2010). Zhao et al. (2010) and Hu et al. $(2016 ; 2019 \mathrm{a}, \mathrm{b})$ pointed out that the model could represent the dust emission distributions and long-range transport processes over the Northern Hemisphere well. In GOCART, the dust emission flux $G$ is calculated as

$G=C S s_{p} u_{10 \mathrm{~m}}^{2}\left(u_{10 \mathrm{~m}}-u_{\mathrm{t}}\right)$,

where $C\left(\mu \mathrm{g} \mathrm{s}^{2} \mathrm{~m}^{-5}\right)$ is defined as a dimensionless empirical proportionality constant with the value of $1.0 \mu \mathrm{g} \mathrm{s}^{2} \mathrm{~m}^{-5}$ provided by Ginoux et al. (2001), $S$ is soil erodibility calculated by a potential dust source function, $s_{p}$ is a fraction of the mass of each size bin of dust emissions, $u_{10 \mathrm{~m}}^{2}\left(\mathrm{~m} \mathrm{~s}^{-1}\right)$ is the horizontal wind speed at $10 \mathrm{~m}$ above the surface, and $u_{\mathrm{t}}$ is the wind speed threshold under which dust emissions do not occur and is a function of surface moisture, air density, and particle size. To match the particle size distribution in the aerosol scheme, the dust mass fractions are set to $45 \%, 26 \%$, $6 \%, 1.5 \%, 0.2 \%, 0.02 \%, 10^{-4} \%$, and $10^{-6} \%$. The dust emissions within the research area are indicated in Fig. 1a. Clearly, dust emission from the TP is much smaller than that of the Gobi and Taklamakan deserts, so the East Asian dust defined here is mainly contributed to by dust emitted from the Gobi and Taklamakan deserts.

\subsection{Other emissions}

The Hemispheric Transport of Air Pollution version 2 (HTAPv2) is used in the simulations, as anthropogenic emissions with a monthly temporal resolution and $0.1^{\circ} \times 0.1^{\circ}$ horizontal resolution (Janssens-Maenhout et al., 2015). The Fire INventory from NCAR (FINN) supplies biomass burning emissions with $1 \mathrm{~km}$ horizontal resolution and hourly temporal resolution (Wiedinmyer et al., 2011), and the vertical distribution follows the injection heights suggested by Dentener et al. (2006). The sea salt emissions were obtained from Jaeglé et al. (2011), depending on sea surface temperature, and Gong (2003), based on the correction of particles with a radius of less than $0.2 \mu \mathrm{m}$.

\subsection{Numerical experiments}

Following $\mathrm{Hu}$ et al. (2016), a quasi-global WRF-Chem simulation was performed at $1^{\circ}$ horizontal resolution with $360 \times 145$ grid cells $\left(180^{\circ} \mathrm{W}-180^{\circ} \mathrm{E}, 67.5^{\circ} \mathrm{S}-77.5^{\circ} \mathrm{N}\right)$ and 35 vertical layers up to $50 \mathrm{hPa}$ over the period of 2010 2015 (Fig. 1b). The lateral meridional boundary conditions and meteorological initial conditions are obtained from the National Center for Environmental Prediction final analysis (NCEP FNL) data at $6 \mathrm{~h}$ temporal and $1^{\circ}$ horizontal resolution. In order to better modeling aerosol long-range transport, the nudged method is used to provide more realistic atmospheric temperature and wind components (Stauffer and Seaman, 1990). In addition, a tracer-tagging method is used to tag and explicitly track dust particles during the intercon- tinental transport. In the model, four dust source regions are selected, i.e., East Asia $\left(25-50^{\circ} \mathrm{N}\right.$ and $\left.75-150^{\circ} \mathrm{E}\right)$, North Africa $\left(0-40^{\circ} \mathrm{N}\right.$ and $\left.20^{\circ} \mathrm{W}-35^{\circ} \mathrm{E}\right)$, North America (15$50^{\circ} \mathrm{N}$ and $80-140^{\circ} \mathrm{W}$ ), and the elsewhere in the world (dominated by the Middle Eastern dust in the Northern Hemisphere, $0-50^{\circ} \mathrm{N}$ and $35-75^{\circ} \mathrm{E}$ ). The dust particles emitted from the four source regions are tagged and explicitly tracked using additional model variables within a single simulation in the model, following $\mathrm{Hu}$ et al. $(2016,2019 \mathrm{a}, \mathrm{b})$ and Mao et al. (2019). During the model simulation, the physical and advective tendencies of all tagged dust variables are treated in the same way. Therefore, the contribution of a dust source to the dust quantity in a receptor region is defined by the ratio of the dust quantity in the receptor region from the dust source to the dust quantity of all sources combined. This direct tagging technique neither introduces aerosol source perturbations to the model nor employs assumptions of aerosol sources/sinks along the transport pathways (Hu et al., 2019a; Mao et al., 2019). Zhao et al. (2013b) pointed out that the updated model could better simulate the distribution of aerosol size and particle number and give more detailed information about the horizontal and vertical distribution of aerosols and the aerosol intercontinental transport process. More detailed information on the numerical experiment, including the physical and chemical schemes, can be found in $\mathrm{Hu}$ et al. (2016).

\section{Satellite retrievals}

\subsection{MODIS}

The AOD datasets obtained from the Moderate Resolution Imaging Spectroradiometer (MODIS) instrument on board the NASA EOS Terra satellite are used to evaluate model simulations. It provides datasets with daily and $1^{\circ} \times 1^{\circ}$ resolution for the period of 2010-2015. In order to better qualify, presumably, the AOD, the "dark target" algorithm is used to retrieve aerosol size parameters and AOD over vegetated and waters lands (Kaufman et al., 1997; Remer et al., 2005), and the "deep blue" algorithm is used to retrieve the AOD over vegetated land and bright targets (Hsu et al., 2006, 2013). The uncertainties in the merged AODs (at $550 \mathrm{~nm}$ ) from MODIS Collection 6 are about 0.11 over the globe and 0.069 over northeast Asia (Sayer et al., 2014) when compared with AErosol RObotic NETwork (AERONET) observations. In this study, the dark-target-retrieved AOD over ocean and deep-blue-retrieved AOD over land are merged in MODIS Collection 6.

\subsection{MISR}

The AOD from the Multi-angle Imaging SpectroRadiometer (MISR) Level 2 version 23 aerosol data is also used. MISR instrument on board the Terra spacecraft is designed to view the Earth using nine separate cameras. Four spectral bands 
(a)

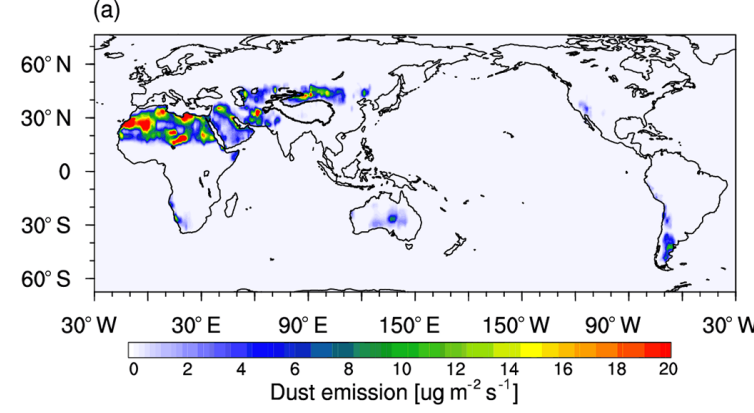

(b)

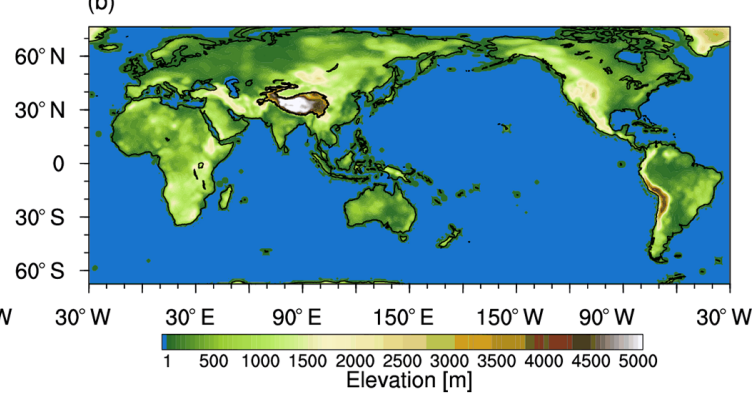

Figure 1. Spatial distribution of annual mean (a) dust emission (micrograms per square meter per second) and (b) elevation (meters) simulated in WRF-Chem for the period of 2010-2015.

(centered at 446, 558, 672, and $866 \mathrm{~nm}$ ) are measured along the orbital track angles with a range of $\pm 70.5^{\circ}$ (Diner et al., 1998). They can provide well the retrieval of AOD daily products (Level 2) with a spatial resolution of $0.5^{\circ} \times 0.5^{\circ}$, especially over highly reflective surfaces such as deserts (Martonchik et al., 2002). The uncertainties in the MISR AOD (version 23) is about 0.049 , which is more realistic than the 0.003 uncertainty in version 22 products (Witek et al., 2018). Here, we compare the MISR AOD at $550 \mathrm{~nm}$ from Level 2 with the model results. Notice that the model results are sampled in the same time as the MISR overpass.

\subsection{CALIPSO}

The aerosol extinction profiles retrieved by the CloudAerosol Lidar with Orthogonal Polarization (CALIOP) are used in this study. It was launched into a Sun-synchronous orbit on board the CALIPSO satellite on 28 April 2006. The vertical profiles of attenuated backscatter can be acquired during both night and day (Winker et al., 2007). The CALIPSO level 3 profile products, which are retrieved from level 2 aerosol profile datasets through a quality screen, are used to evaluate the model. For the CALIPSO aerosol extinction retrievals, the uncertainties are mainly determined by the lidar ratio and the misclassification of aerosol type (Winker et al., 2009). Yu et al. (2010) reported that the fraction of uncertainty in the lidar ratio is about $30 \%$, which could result in an AOD fraction of uncertainty of about $50 \%$ (for the AOD it is about 0.5). Moreover, the dust extinction at $532 \mathrm{~nm}$ with the vertical resolution of $60 \mathrm{~m}$ (from -0.5 to $12 \mathrm{~km}$ ) and the spatial resolution of $5^{\circ} \times 2^{\circ}$ (longitude $\times$ latitude) is used. In this study, the CALIOP nighttime observations are used to compare with the dust extinction profiles of the model in cloud-free conditions, because the CALIOP observations are influenced less by noises during nighttime than during daytime (Winker et al., 2010).

\section{Evaluation of AOD and dust AOD simulated by WRF-Chem}

Figure 2 illustrates the spatial distributions of the observed (MODIS and MISR on board Terra) and modeled (WRFChem simulation) seasonal AOD at $550 \mathrm{~nm}$ for the period of 2010-2015. The simulated AOD is interpolated at $550 \mathrm{~nm}$ using the Ångström exponent from 400 and $600 \mathrm{~nm}$ results due to the wavelength discrepancy between simulations and observation. Also, we extract and average the simulated AOD at 10:30 LT (local time) to match the MISR and MODIS retrievals. Because of the missing values of satellite retrievals, there are blank areas over the ocean, which are relatively larger from June through August (JJA) (Hu et al., 2016). The MODIS retrievals show a higher AOD over anthropogenic polluted regions (i.e., eastern China and southern India) and the major desert regions (i.e., the Sahara, Arabian, Gobi, and Taklamakan deserts) than the MISR retrievals and model simulations. This is partly because the MODIS retrievals overestimate the AOD magnitude in semi-arid regions due to the large uncertainties associated with the assumed surface reflectance (Remer et al., 2005; Levy et al., 2013). Relatively, the MISR characterizes a better land surface reflectance and retrieves better quality values, presumably. Moreover, the simulation overestimated the AOD over the North African deserts and the northern Pacific with the peak value (about 0.16) in spring (March-May; MAM) (Fig. S1 in the Supplement). Over the TP, the simulated AOD is smaller than that of MISR and MODIS, and the difference is about -0.08. Overall, the WRF-Chem-simulated mean AOD shows a consistent spatial pattern when compared with MISR and MODIS retrievals. The spatial correlation coefficients of the AOD are about 0.65 and 0.79 for MODIS and MISR, respectively. The seasonal variabilities of spatial correlation coefficients between the simulation and MODIS (MISR) are 0.55 (0.62), 0.63 (0.66), 0.63 (0.68), and 0.67 (0.75) for winter (December-February; DJF), MAM, JJA, and autumn (September-November; SON), respectively. Over the dust source regions, the simulated results are closer to the MISR retrievals, with the largest AOD (more than 0.6) having a cor- 
relation coefficient of about 0.87 . The trans-Pacific transport of East Asian aerosols and trans-Atlantic transport of Saharan dust are also well simulated and are contained in the studies of Hu et al. (2016) and Yu et al. (2010, 2012). The model also captures the seasonal variabilities of AOD over the major desert regions shown in the satellite retrievals. The maximum AOD over North Africa and the Middle East appears in JJA, while that over East Asia is in MAM.

Globally, the dust emissions often occur over source regions with the terrain elevation generally below $3 \mathrm{~km}$, and then they can be lifted into the upper troposphere (Yu et al., 2008). By using the CALIPSO retrievals, Xu et al. (2018) studied the dust transport at different altitudes and found that the TP had an important impact on global dust longrange transport to the upper troposphere. In order to evaluate the model results, we compare the spatial distribution of annual dust AOD from WRF-Chem between 0-3, 3-6, 6-9, and $9-12 \mathrm{~km}$ with the CALIPSO results (Fig. 3). It shows that the model simulations reasonably reproduce the spatial distributions of dust AOD at different altitudes with correlation coefficients of $0.71(0-3 \mathrm{~km}), 0.86(3-6 \mathrm{~km}), 0.49$ (6$9 \mathrm{~km})$, and $0.32(9-12 \mathrm{~km})$. The maximum dust AOD appears around the dust sources between $0-3 \mathrm{~km}$, with a peak value of 0.6 , in which the overestimation of the simulation (more than 0.06) is over the North African deserts and the underestimation (less than -0.06) is over the Middle East and India (Fig. S2). Between 3-6 km, the model has a similar spatial distribution to the CALIPSO results at $0-3 \mathrm{~km}$. The positive difference is about 0.02 over the North African deserts, and the negative difference is about -0.02 over southern Arabian Peninsula, Somali Peninsula, and the northern slope of the TP (Fig. S2). Between 6-9 and 9-12 km, the modeled dust AODs are higher than CALIPSO, with a positive difference of 0.001-0.01 (Fig. S2), which is possibly induced by model biases, such as those related to circulation conditions.

\section{Result}

\subsection{Characteristics of dust transport from different source regions}

The TP is surrounded by several large deserts. On the northern side, the major Taklimakan and Gobi deserts emit mineral dust particles that can be transported into the TP and elevated to a very high altitude, i.e., approximately $4-7 \mathrm{~km}$ (Huang et al., 2007) in most years and up to $12 \mathrm{~km}$ during some extreme conditions (Liu et al., 2008). Also, the dust particles from deserts on the western side (i.e., the Thar desert and the Middle East desert) could be brought into the TP by the westerlies (Jin et al., 2016; Lau et al., 2016). Hu et al. (2019a) has pointed out that the North African dust mixes with the Middle Eastern dust before being carried into East Asia. In order to better describe the impact of dust from different sources over the TP, the horizontal spatial distributions of annual mean dust mass loading emitted from East Asia (Fig. 4a), North Africa (Fig. 4b), and the Middle East (Fig. 4c) are illustrated. Clearly, the East Asian dust dominates the northern slope of the TP and even extends to the southern TP. Meanwhile, the dust mass loading decreases with altitude. At $0-3 \mathrm{~km}$, the maximum dust mass loading occurs over the source regions with a value of more than $200 \mathrm{mg} \mathrm{m}^{-2}$. At $3-$ $6 \mathrm{~km}$, dust can rise up to the TP and even reach the southern edge of the TP. Over the northern slope, the dust mass loading is about 50 and $10 \mathrm{mg} \mathrm{m}^{-2}$ at 3-6 and 6-9 km, respectively. At $9-12 \mathrm{~km}$, the dust $\left(5 \mathrm{mg} \mathrm{m}^{-2}\right)$ appears over the TP due to the effect of the TP orography. Compared with other sources, the East Asian desert contributes more than $90 \%$ at $0-3 \mathrm{~km}$ over the northern slope of the TP. At $3-6 \mathrm{~km}$, the contribution from East Asian dust dominates north of $35^{\circ} \mathrm{N}$ with a contribution of about $80 \%$. However, the contribution decreases to $40 \%$ above $6 \mathrm{~km}$ because of the mixing of dust particles from North Africa and the Middle East (Fig. 4b and c). It is worth noting that there are significant dust plumes over the TP (Fig. 3), especially in the northeast region. This dust transport can be attributed to the effect of the TP, which could provide more favorable conditions (i.e., cyclonic and dry convection) to make dust uplift into the upper troposphere (Xu et al., 2018).

The North African dust can be transported westward across the Atlantic Ocean by African easterly waves, which are a major global dust long-range transport and have been addressed by many studies (e.g., Liu et al., 2008; Su and Toon, 2011; Nowottnick et al., 2011; Ben-Ami et al., 2012; Yu et al., 2013). Beyond that, the North African dust could transport into Europe (Park et al., 2005; Lee et al., 2010) and the Middle East (Hu et al., 2019a). Hu et al. (2019a) pointed out that the North African dust mixed with the Middle Eastern dust could be transported eastward and carried into East Asia. During the eastward transport, the TP stands in the way and plays an important role in affecting the dust transport and vertical distribution over the TP. Clearly, the TP can affect the intercontinental dust transport and split it into two branches below $6 \mathrm{~km}$ (Fig. 4b). When above $6 \mathrm{~km}$, the major dust transport appears over the northern branch, and this can be attributed to the northward shift of the easterlies (Yu et al., 2008). Meanwhile, more wet deposition induced by Indian summer monsoon rainfall over the southern branch can reduce the dust transport. The North African dust brought $10 \mathrm{mg} \mathrm{m}^{-2}$ of mass loading over the southern slope below $3 \mathrm{~km}$, but the dust can reach the northern slope with the value of $10 \mathrm{mg} \mathrm{m}^{-2}$ at $6-9 \mathrm{~km}$. Compared with East Asia, North Africa dominates contributions above $6 \mathrm{~km}$ with a value of $40 \%$.

Similar to the North African dust eastward transport, the Middle Eastern dust can also be transported into East Asia (Hu et al., 2019a). Over the TP, the dust mass loading is about $50 \mathrm{mg} \mathrm{m}^{-2}$ at $3-6 \mathrm{~km}$, which is concentrated over both of the southern and northern slopes (Fig. 4c). At the higher altitude, the dust can pass over the TP with $10 \mathrm{mg} \mathrm{m}^{-2}$ at 6- 

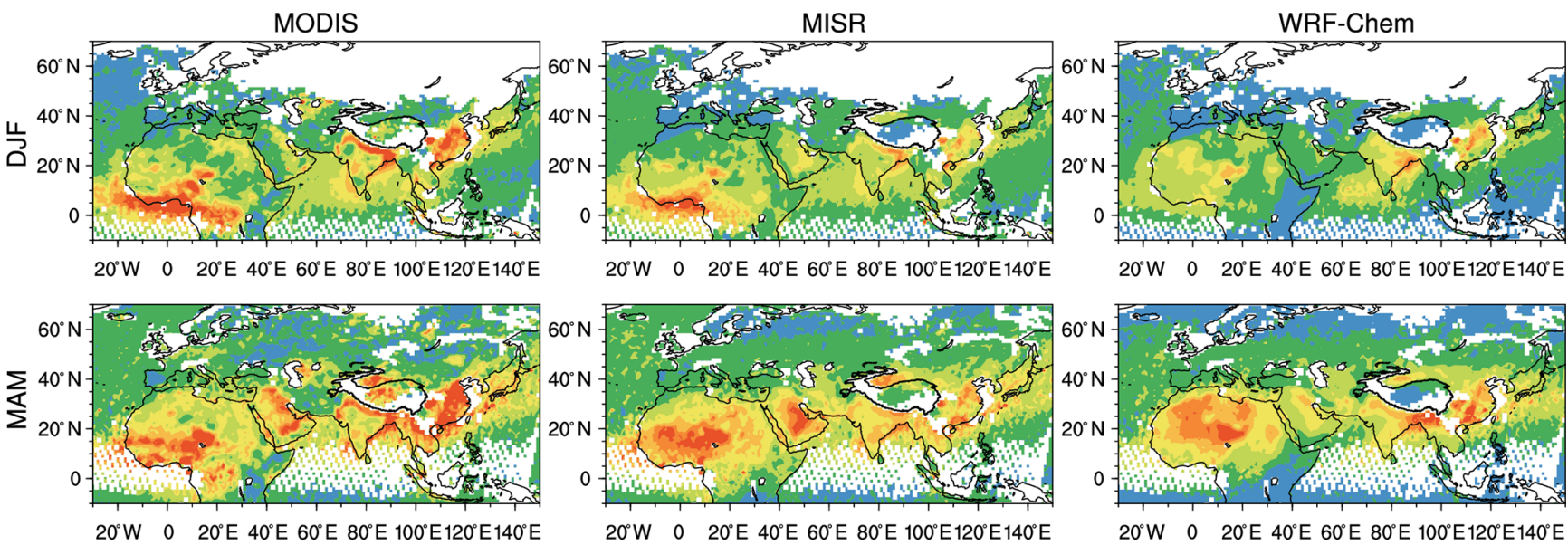

$20^{\circ} \mathrm{W} \quad 0 \quad 20^{\circ} \mathrm{E} 40^{\circ} \mathrm{E} 60^{\circ} \mathrm{E} 80^{\circ} \mathrm{E} 100^{\circ} \mathrm{E} 120^{\circ} \mathrm{E} 140^{\circ} \mathrm{E}$
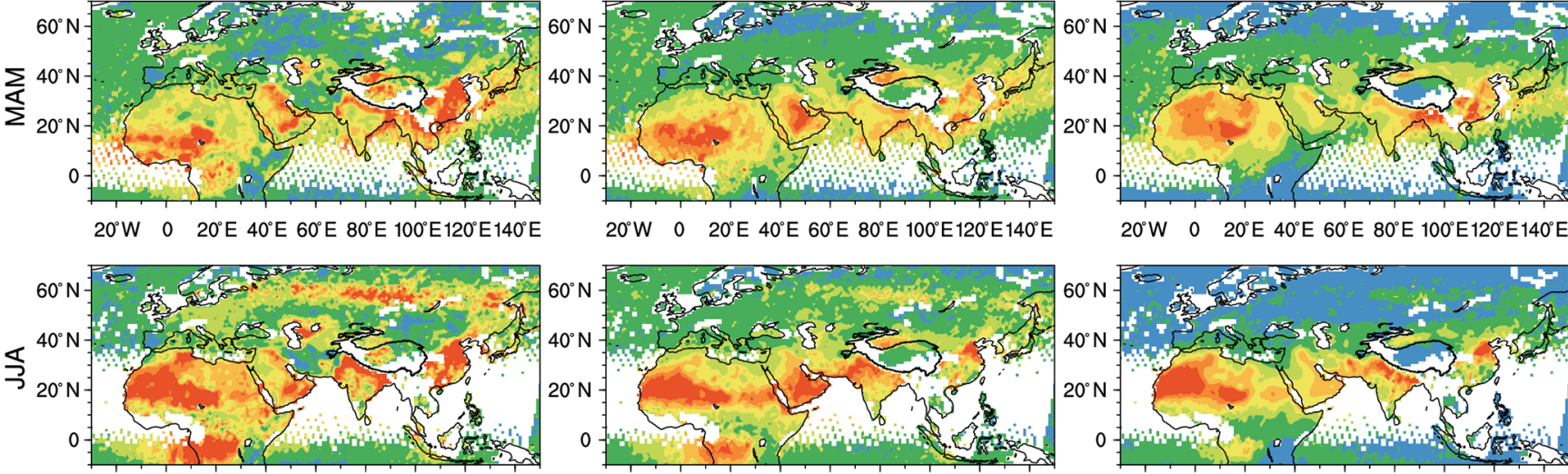

$20^{\circ} \mathrm{W} \quad 20^{\circ} \mathrm{E} 40^{\circ} \mathrm{E} 60^{\circ} \mathrm{E} 80^{\circ} \mathrm{E} 100^{\circ} \mathrm{E} 120^{\circ} \mathrm{E} 140^{\circ} \mathrm{E}$

$20^{\circ} \mathrm{W} \quad 0 \quad 20^{\circ} \mathrm{E} 40^{\circ} \mathrm{E} 60^{\circ} \mathrm{E} 80^{\circ} \mathrm{E} 100^{\circ} \mathrm{E} 120^{\circ} \mathrm{E} 140^{\circ} \mathrm{E}$

$20^{\circ} \mathrm{W} \quad 020^{\circ} \mathrm{E} 40^{\circ} \mathrm{E} 60^{\circ} \mathrm{E} 80^{\circ} \mathrm{E} 100^{\circ} \mathrm{E} 120^{\circ} \mathrm{E} 140^{\circ} \mathrm{E}$

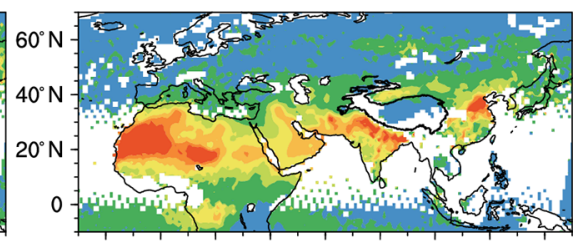

$20^{\circ} \mathrm{W} \quad 20^{\circ} \mathrm{E} 40^{\circ} \mathrm{E} 60^{\circ} \mathrm{E} 80^{\circ} \mathrm{E} 100^{\circ} \mathrm{E} 120^{\circ} \mathrm{E} 140^{\circ} \mathrm{E}$

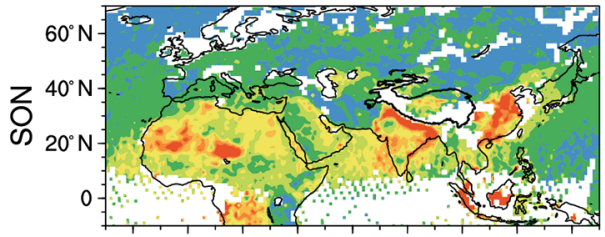

$20^{\circ} \mathrm{W} \quad 2 \quad 20^{\circ} \mathrm{E} 40^{\circ} \mathrm{E} 60^{\circ} \mathrm{E} 80^{\circ} \mathrm{E} 100^{\circ} \mathrm{E} 120^{\circ} \mathrm{E} 140^{\circ} \mathrm{E}$
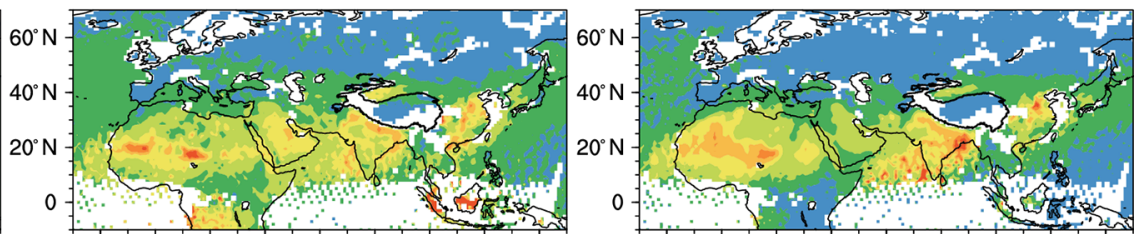

$20^{\circ} \mathrm{W} \quad 20^{\circ} \mathrm{E} 40^{\circ} \mathrm{E} 60^{\circ} \mathrm{E} 80^{\circ} \mathrm{E} 100^{\circ} \mathrm{E} 120^{\circ} \mathrm{E} 140^{\circ} \mathrm{E}$

$20^{\circ} \mathrm{W} \quad 0 \quad 20^{\circ} \mathrm{E} 40^{\circ} \mathrm{E} 60^{\circ} \mathrm{E} 80^{\circ} \mathrm{E} 100^{\circ} \mathrm{E} 120^{\circ} \mathrm{E} 140^{\circ} \mathrm{E}$

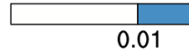

0.1

AOD at $500 \mathrm{~nm}$

Figure 2. Spatial distributions of seasonal mean AOD at $550 \mathrm{~nm}$ from the retrievals of MODIS and MISR on board Terra and from the WRF-Chem simulation for the period of 2010-2015. The daily results from MISR, MODIS, and WRF-Chem are only sampled for averaging when all of them have valid values at the same location and time.

$9 \mathrm{~km}$ and $5 \mathrm{mg} \mathrm{m}^{-2}$ at $9-12 \mathrm{~km}$. Also, the Middle Eastern dust is transported north over $30^{\circ} \mathrm{N}$, and this is similar to the North African dust above the $6 \mathrm{~km}$. Different from North Africa and East Asia, the contribution from the Middle Eastern dust is concentrated over the southern slope of the TP, and the value decreases with the altitude. Below $3 \mathrm{~km}$, the maximum contribution value occurs over the source region (more than $90 \%$ ). At $3-6 \mathrm{~km}$, the contribution is about $80 \%$ over the southern slope, and the value reduces to $60 \%$ at $6-$ $12 \mathrm{~km}$.

Figure 5 illustrates the annual mean wind field in the horizontal (denoted by arrows) and vertical directions (indicated by the colors) at various altitudes from the WRF-Chem simulations for the period of 2010-2015. The positive (negative) value of the vertical wind velocity shows it to be an updraft (downdraft). At 0-3 km, the updrafts appear over major dust source regions, i.e., the Sahara, Arabian, Thar, Gobi, and Taklamakan deserts. Because of the updrafts, dust particles are emitted into the atmosphere over the sources and then transport to downwind regions (Fig. 4a, b, and c). At 3-6 km, a significant updraft occurs around the TP, especially over the southern slope. Therefore, the dust from the Middle East and North Africa accounts for a larger fraction of the contribution than the northern slope. At 6-9 and 9-12 km, the updraft over the TP reaches $0.012 \mathrm{~m} \mathrm{~s}^{-1}$, which is greater than the vertical wind velocity over the surrounding areas. This could be attributed to the dynamical (Huang et al., 2008; Liu et al., 2008) and thermal forcing due to the TP (Lau et al., 2006) on the atmospheric flows. Under these updraft conditions, the dust particles can be brought into the upper troposphere ( $\sim 12 \mathrm{~km})$, which is consistent with the results from CALISPO observations (Liu et al., 2008). Also, the horizontal and vertical wind has significant seasonal variability (Fig. S3). At the $0-3 \mathrm{~km}$, the maximum updrafts appear in JJA over major dust source regions, followed by MAM. Over the TP, the updrafts are clearly in JJA, while the downdrafts dominate in DJF. In MAM and SON, the updrafts and downdrafts occur in a spatially uniform way. Additionally, the vertical wind is 

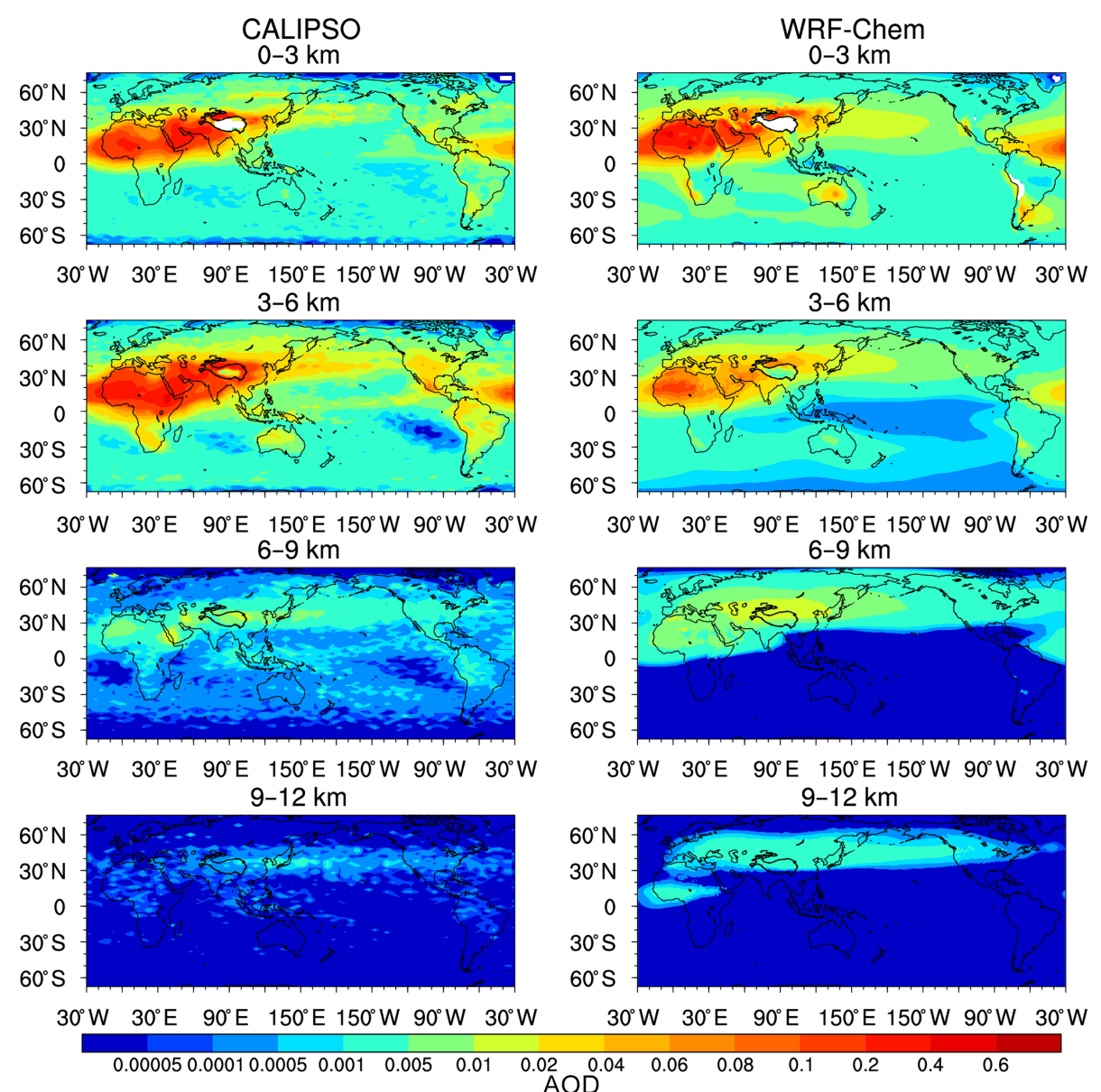

Figure 3. Spatial distributions of annual mean dust AOD from CALIPSO (left) and WRF-Chem (right) between 0-3, 3-6, 6-9, and 9-12 km for the period of 2010-2015.

ascending at 3-6 km on the southern fringe of the TP across all seasons, while the vertical wind is descending above $6 \mathrm{~km}$ in DJF, MAM, and SON.

To describe the transport characteristics of dust from various deserts, we analyze the vertical cross sections of meridional circulation and zonal dust mass concentration at 75, 90, and $102^{\circ} \mathrm{E}$ (Fig. 6). The three longitudes crossed the TP are denoted by purple solid lines in Fig. 4a. Clearly, a large dust mass from East Asia and the Middle East is accumulated over the northern and southern slope of the TP, then lifted up to the TP due to orographic lifting. The East Asian dust is lifted up to the TP from its northern slope, and a majority of the Middle Eastern dust is lifted from the southern slope. Also, the strong northwesterly wind can transport the East Asian dust continuously eastward (Liu et al., 2015) and the dust mass concentration increases significantly from 75 to $102^{\circ} \mathrm{E}$. The Middle Eastern dust is carried into the TP along with the westerly wind, but the dust mass concentration decrease from 75 to $102^{\circ} \mathrm{E}$. The vertical height-latitude cross section of the modeled dust mass concentration centered at $90^{\circ}$ E suggests that the dust particles can lift up to $9 \mathrm{~km}$ with a concentration value of $2 \mu \mathrm{g} \mathrm{m}^{-3}$, especially for the Middle Eastern dust (higher than $10 \mathrm{~km}$ ). Different from the East Asian and Middle Eastern dust, the North African dust has a peak mass concentration $\left(\sim 4 \mu \mathrm{g} \mathrm{m}^{-3}\right)$ in the $3-8 \mathrm{~km}$ (at $90^{\circ} \mathrm{E}$ ) after being carried into the TP.

Figure 7 shows the vertical height-longitude cross section at 24,36 , and $38^{\circ} \mathrm{N}$ of the zonal circulation and meridional dust mass concentration from the WRF-Chem simulation for the period of 2010-2015. These latitudes are the same as in $\mathrm{Xu}$ et al. (2018), which can represent well the dust zonal transport over the TP. The maximum East Asian dust mass concentration is located at the $80-120^{\circ} \mathrm{E}$, and the maximum North African and Middle Eastern dust concentrations are at $20^{\circ} \mathrm{W}-40^{\circ} \mathrm{E}$ and $30-80^{\circ} \mathrm{E}$, respectively. These distributions are consistent with their source regions. The dust emitted from East Asia is lifted up to the TP at $38^{\circ} \mathrm{N}$, with a peak mass concentration of $40 \mu \mathrm{g} \mathrm{m}^{-3}$, then arrives over the TP (at $36^{\circ} \mathrm{N}$ ) with a value of $2-10 \mu \mathrm{g} \mathrm{m}^{-3}$. After passing through the TP, there are very few dust particles over the southern slope of the TP. Because the dust from North Africa and the Middle East is mainly concentrated over $30^{\circ} \mathrm{N}$ and to the 

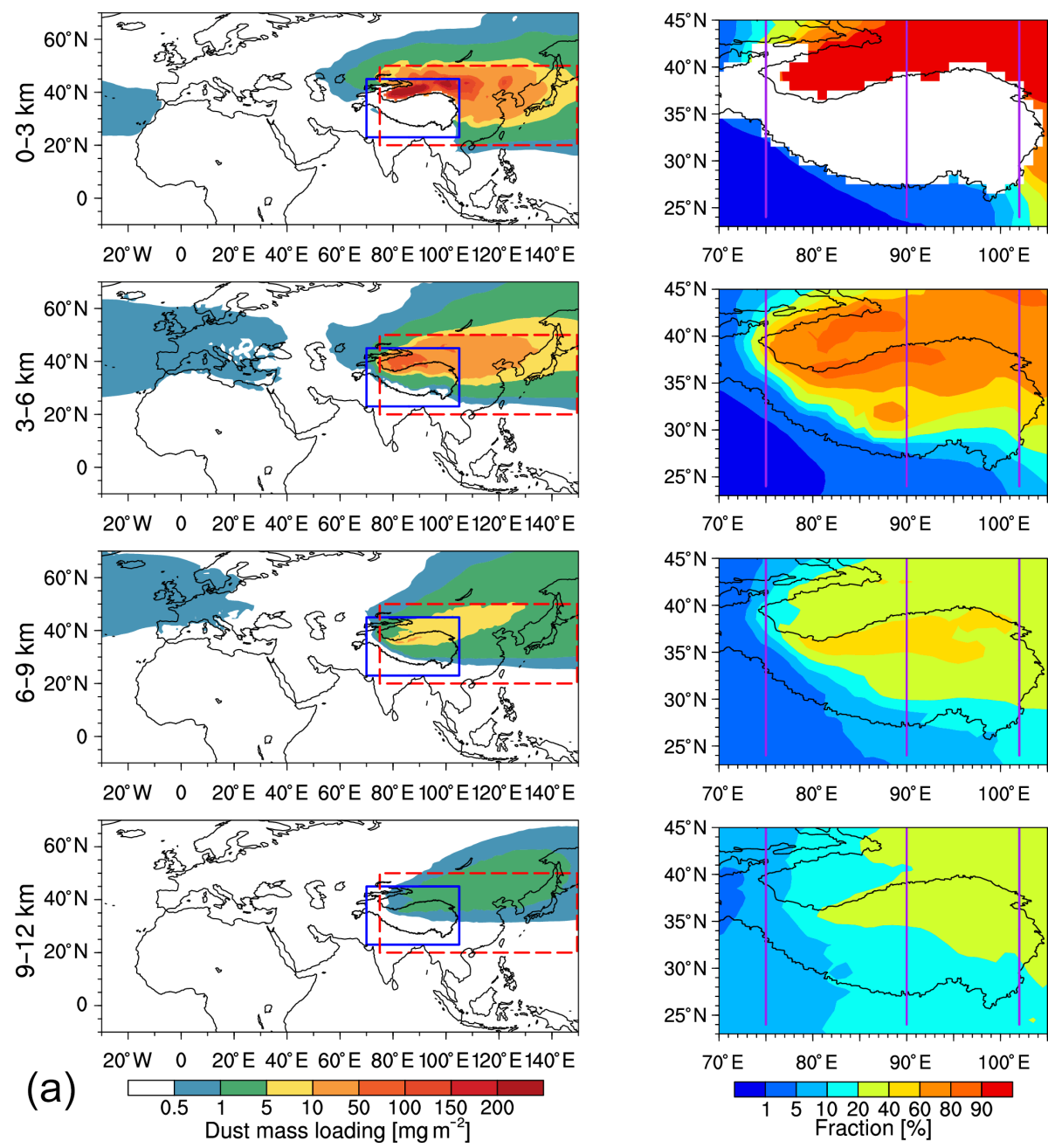

Figure 4.

north, the eastward transport of dust particles is not significant. At 36 and $38^{\circ} \mathrm{N}$, eastward transport of the dust is larger, with two peaks on both sides of $100^{\circ} \mathrm{E}$. These peak values are attributed to the updraft on the western side and downdraft on the eastern side in the westerly circulation.

Overall, the East Asian dust is lifted up to the TP over the northern slope and the Middle Eastern dust is lifted up over the southern slope (Fig. 4a and b). However, the North African dust is important into the TP in a higher altitude (Fig. 5). Above $3 \mathrm{~km}$, the westerly wind is effected by the $\mathrm{TP}$, which results in the major transport pathway of dust being north of $30^{\circ} \mathrm{N}$ (Fig. $4 \mathrm{a}, \mathrm{b}$ and c). At a higher altitude (above $6 \mathrm{~km}$ ), the major contributor of dust over the TP is the Middle Eastern dust, with a value $60 \%$. Obviously, the dust particles can be brought to $9 \mathrm{~km}$ under the TP orographic effect (Fig. 5).

\subsection{Dust mass flux flowing into and flowing out from the TP}

The annual dust mass flux carried into or flowing out from the boundaries of the TP at various altitudes is shown in Fig. 8 . In order to better describe the dust mass flux carried into or flowing out from the TP, we use the meridional wind to calculate the dust mass flux at the west side $\left(75^{\circ} \mathrm{E}\right)$ and east side $\left(104^{\circ} \mathrm{E}\right)$, with the latitude range of $27-38^{\circ} \mathrm{N}$, and the zonal wind to calculate the dust mass flux at the north $\left(38^{\circ} \mathrm{N}\right)$ and south sides $\left(27^{\circ} \mathrm{N}\right)$, with a longitude range of $75-104^{\circ} \mathrm{E}$. The annual dust mass carried into the TP from the west side is dominated by Middle Eastern dust $\left(26.6 \mathrm{Tg} \mathrm{yr}^{-1}\right)$, followed by North African dust $\left(7.8 \mathrm{Tg} \mathrm{yr}^{-1}\right)$. The Middle Eastern dust mass flux decreases from $12.3 \mathrm{Tg} \mathrm{yr}^{-1}(0-3 \mathrm{~km})$ to $1.2 \mathrm{Tg} \mathrm{yr}^{-1}(9-12 \mathrm{~km})$ with the altitude. The North African dust mass flux increases from the surface to $9 \mathrm{~km}$ with a peak value of $3.3 \mathrm{Tg} \mathrm{yr}^{-1}$. At $9-12 \mathrm{~km}$, the North African dust mass flux $\left(1.4 \mathrm{Tg} \mathrm{yr}^{-1}\right)$ is greater than Middle Eastern dust mass flux $\left(1.2 \mathrm{Tg} \mathrm{yr}^{-1}\right)$. Over the east side, the dust 

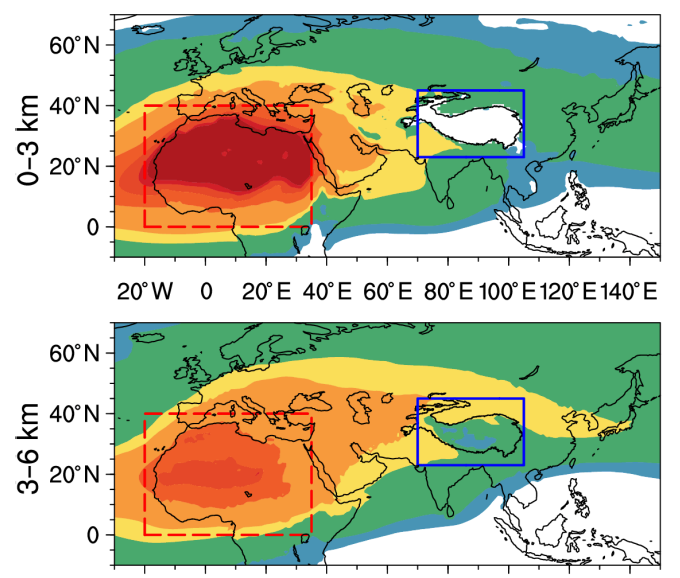

$20^{\circ} \mathrm{W} \quad 2 \quad 20^{\circ} \mathrm{E} 40^{\circ} \mathrm{E} 60^{\circ} \mathrm{E} 80^{\circ} \mathrm{E} 100^{\circ} \mathrm{E} 120^{\circ} \mathrm{E} 140^{\circ} \mathrm{E}$
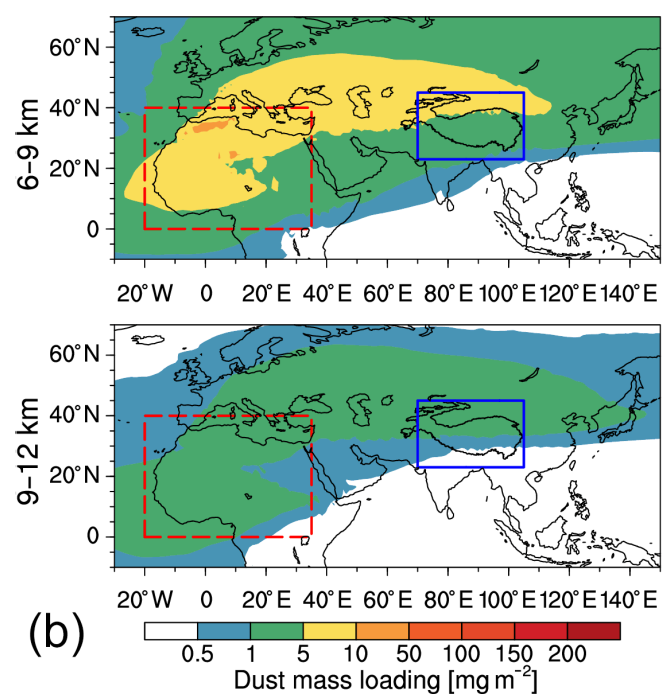
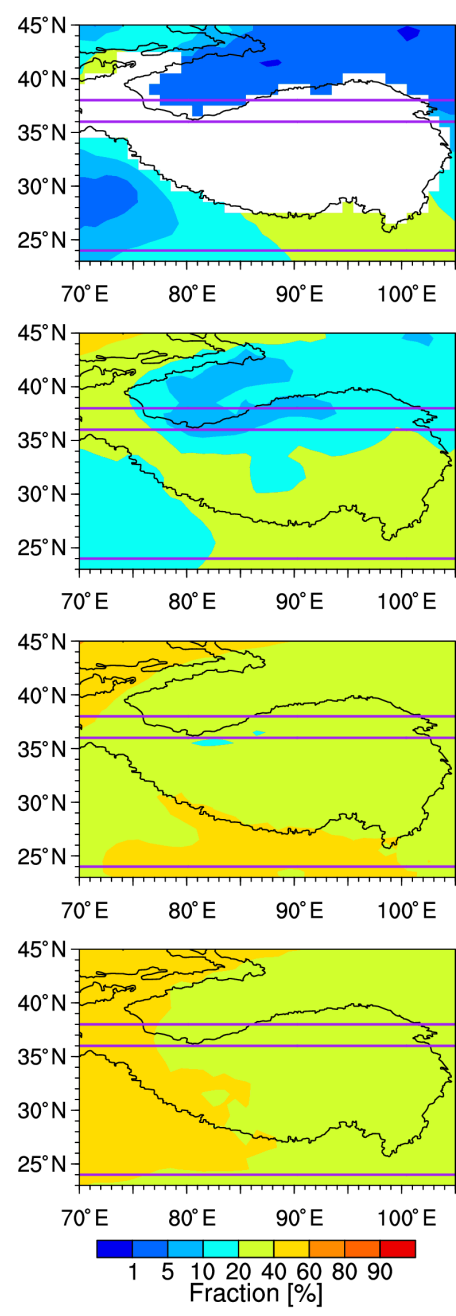

Figure 4.

mainly flows out from the TP with a peak value $\left(8.7 \mathrm{Tg} \mathrm{yr}^{-1}\right)$ at $6-9 \mathrm{~km}$. Impacted by East Asian dust, the dust mass flux over the north side is dominated by the East Asian dust with a peak value $\left(6.2 \mathrm{Tg} \mathrm{yr}^{-1}\right)$ at $3-6 \mathrm{~km}$, followed by $0-3 \mathrm{~km}$ $\left(3.1 \mathrm{Tg} \mathrm{yr}^{-1}\right)$. At $6-9 \mathrm{~km}$, North Africa contributes about $1.1 \mathrm{Tg} \mathrm{yr}^{-1}$, while the East Asia contributes $-0.9 \mathrm{Tg} \mathrm{yr}^{-1}$ (outflow) due to the westerly wind shift to the north (Fig. 5). At $9-12 \mathrm{~km}$, the East Asian dust mass flux is $-0.5 \mathrm{Tg} \mathrm{yr}^{-1}$. Over the south side, the dust is mainly flowing out from the TP with a maximum value originating from the Middle East $\left(-10.4 \mathrm{Tg} \mathrm{yr}^{-1}\right)$ below $6 \mathrm{~km}$. The Middle Eastern (North African) mass flux is about $-5.0(-0.5) \mathrm{Tg} \mathrm{yr}^{-1}$ at $0-3 \mathrm{~km}$ and $-4.2(-0.6) \mathrm{Tg} \mathrm{yr}^{-1}$ at $3-6 \mathrm{~km}$.

Although most case studies of dust aerosols have been focused on the late spring and early summer over the TP (Huang et al., 2008; Chen et al., 2013; Liu et al., 2015), seasonal variabilities of long-range transported dust at different altitude are not well understood. Figure 9 shows the model-based estimation of annual dust mass flux between $0-3,3-6,6-9$, and $9-12 \mathrm{~km}$ over the TP for the period of
2010-2015. It should be noted that the TP is defined as 27$38^{\circ} \mathrm{N}$ and $75-103^{\circ} \mathrm{E}$ (Fig. S4), which shows that some areas within the TP domain have an altitude of less than $3 \mathrm{~km}$. Clearly, the dust mainly is carried into the TP below $6 \mathrm{~km}$. At $0-3 \mathrm{~km}$, the peak inflow and outflow are in JJA and MAM, with fluxes of 7.2 and $2.1 \mathrm{Tg}$, respectively. The weakest inflow (outflow) is in DJF, with a magnitude of $0.82 \mathrm{Tg}(0.6 \mathrm{Tg})$ for the mass flux. At $3-6 \mathrm{~km}$, the inflow and outflow is the greatest in MAM. The maximum value is 8.9 and $4.4 \mathrm{Tg}$, respectively. Differently, the second greatest inflow is in JJA (5.6 Tg), but the second greatest outflow is in DJF $(2.7 \mathrm{Tg})$. The minimum season of in- and outflow is SON, with mass fluxes of $2.0 \mathrm{Tg}$ (inflow) and $1.5 \mathrm{Tg}$ (outflow). At 6-9 km, the peak value is in MAM with mass fluxes of $4.6 \mathrm{Tg}$ (inflow) and 5.3 Tg (outflow), followed by DJF (2.2 Tg for inflow and $2.4 \mathrm{Tg}$ for outflow). At $9-12 \mathrm{~km}$, the peak value occurs in MAM, with the inflow mass flux of $1.8 \mathrm{Tg}$ and the outflow mass flux of $2.7 \mathrm{Tg}$, which account for about $50 \%$ and $54 \%$ of the annual flux, respectively. Moreover, we can see that the outflow is greater than the inflow above $6 \mathrm{~km}$ while the 

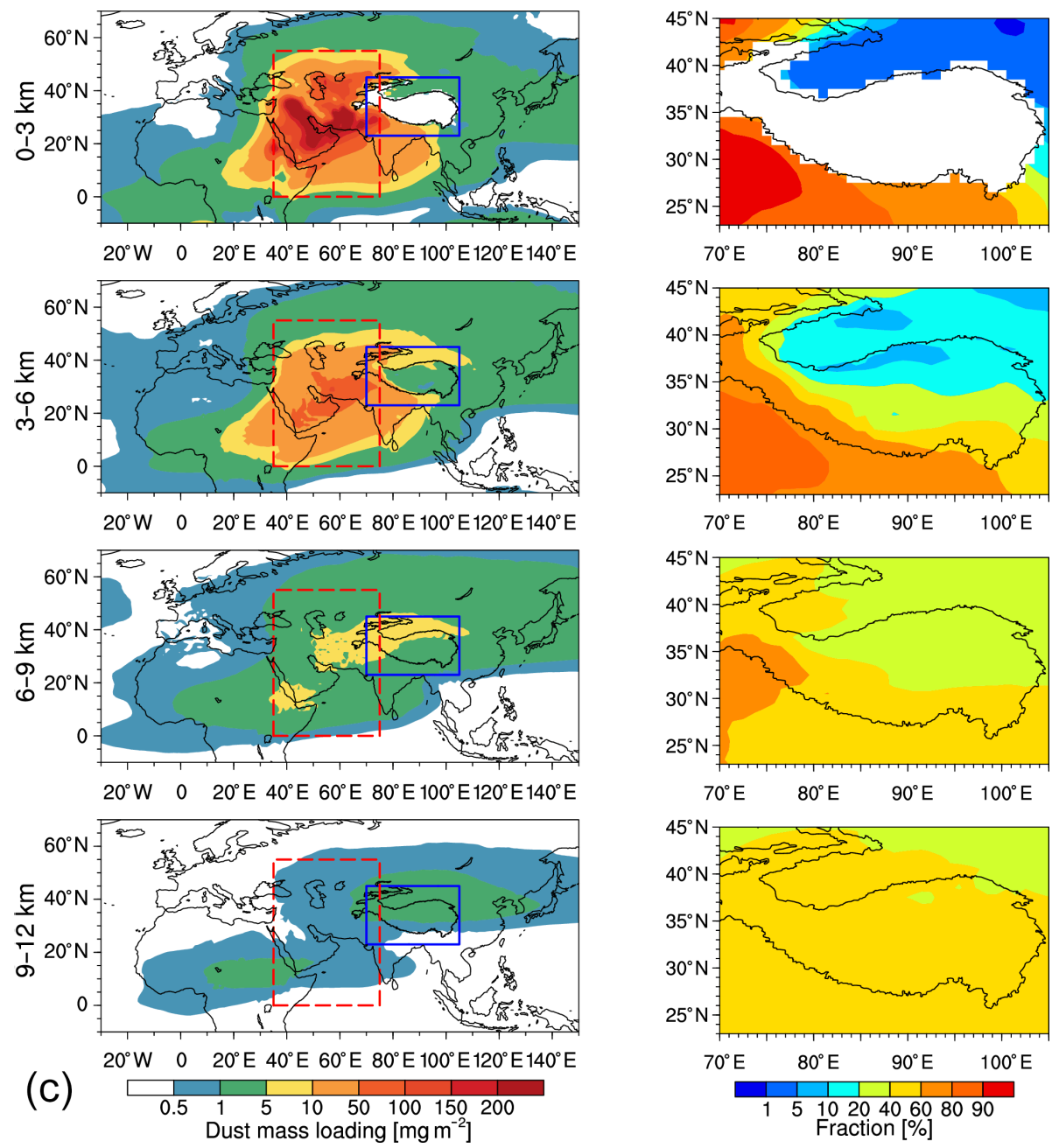

Figure 4. (a) Spatial distributions of (left) annual mean dust mass loading (in milligrams per square meter) emitted from East Asia between $0-3,3-6,6-9$, and 9-12 km and (Right) the corresponding fractions compared with total dust mass loading over TP. The box in red dotted lines shows the dust source regions, while the box in blue solid lines shows the TP regions in this study. The purple solid lines are at 75,90 and $102^{\circ} \mathrm{E}$ for the dust height-latitude cross sections. (b) Same as (a) but for dust emitted from North Africa. The purple solid lines are at 24, 36 and $38^{\circ} \mathrm{N}$ for the dust height-longitude cross sections. (c) Same as (a) but for dust emitted from the Middle East.

inflow is greater than the outflow below $6 \mathrm{~km}$, especially at 9-12 km due to the effect of the TP topography.

\subsection{Characteristics of size distribution of dust over the TP}

Dust size representation can significantly influence the dust mass balance in the atmosphere and dry/wet dust deposition (Zhao et al., 2013b). In order to better understand the dust particle characteristics over the TP, the vertical distribution of dust mass vs. dust particle size from 0.039 to $10.0 \mu \mathrm{m}$ over the TP is analyzed in Fig. 10a. Obviously, dust mass vertical distribution vs. dust size has significant seasonal and altitudinal variabilities. The East Asian dust dominates in the size range of $1.25-10.0 \mu \mathrm{m}$ above $1 \mathrm{~km}$, in which the maximum dust mass concentration (up to $4 \mu \mathrm{g} \mathrm{m}^{-3}$ ) ranges in size from 2.5 to $5.0 \mu \mathrm{m}$, with a peak in MAM, followed by JJA. This is consistent with previous studies in which the Taklimakan Desert has a peak emission rate of dust in MAM (i.e., Huang et al., 2008; Chen et al., 2013; Liu et al., 2015). The North African dust mass is mainly in the range of 1.25$5.0 \mu \mathrm{m}$, which is smaller than those of East Asia and the Middle East. This is likely attributed to the larger particles scavenged more easily by dry/wet deposition during dust intercontinental transport, and fine particles can be more easily transported and reside in the atmosphere. Also, the maximum dust mass concentration is centered at $2.5 \mu \mathrm{m}$, and these particles can reach about $9 \mathrm{~km}$ in MAM, followed by DJF. Similar to the East Asian dust, the Middle Eastern dust mass is concentrated in the size range of $1.25-10.0 \mu \mathrm{m}$ below $3 \mathrm{~km}$, in which the maximum mass concentration ranges in size from 1.25 to $5.0 \mu \mathrm{m}$, with a peak (up to $10 \mu \mathrm{g} \mathrm{m}^{-3}$ ) in MAM, 

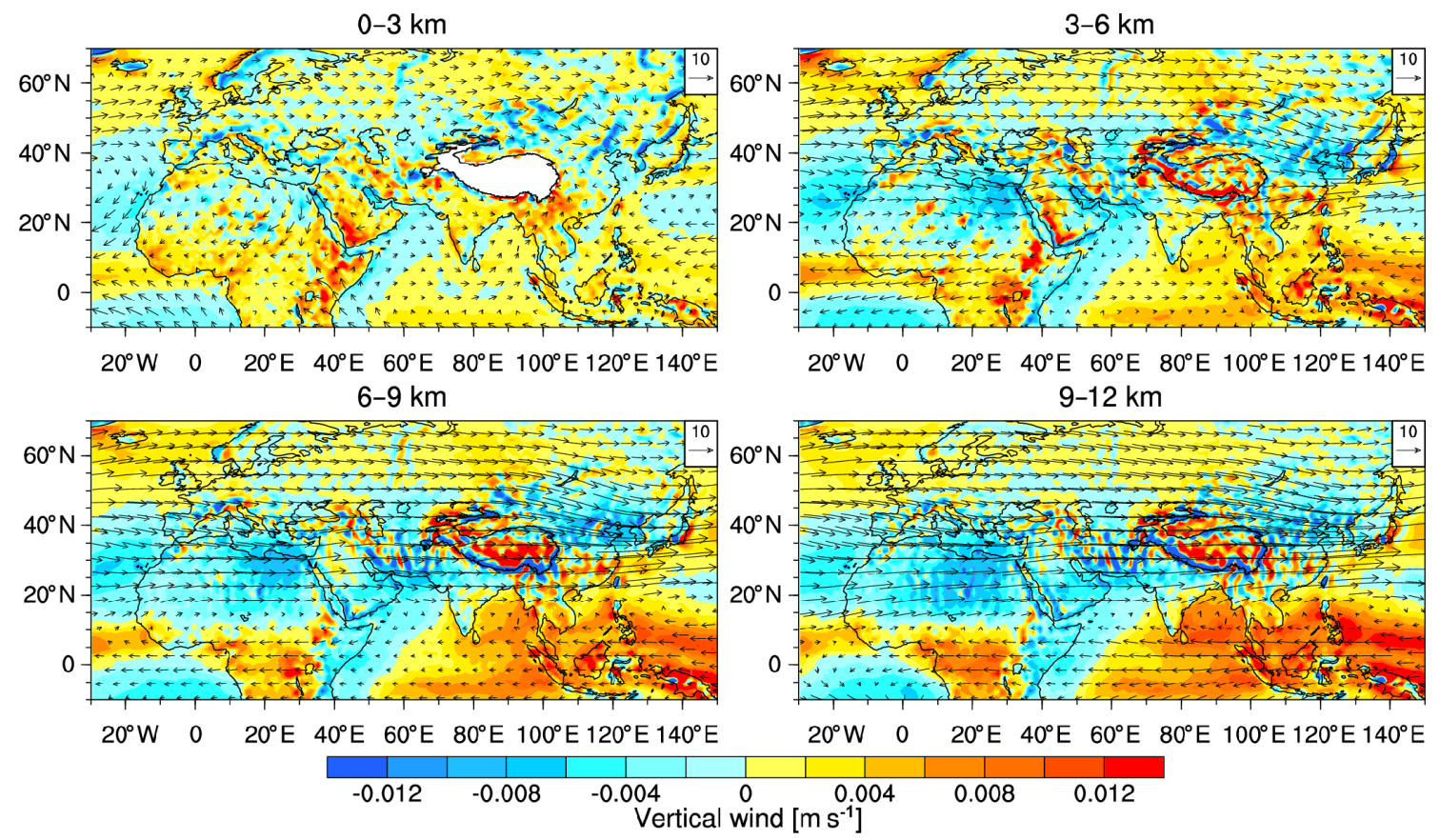

Figure 5. Annual mean wind field between 0-3, 3-6, 6-9, and 9-12 km from the WRF-Chem simulations for the period of 2010-2015. The arrows indicate the horizontal wind (meters per second). The colors indicate the vertical wind velocity (meters per second) and positive values are for updrafts and negative values are for downdrafts.

followed by JJA. Above $3 \mathrm{~km}$, the Middle Eastern dust has similar seasonal and vertical distribution of different particle sizes compared to the East Asian dust, both of which can reach a height of $12 \mathrm{~km}$.

Beside dust mass and AOD, dust particle number is another critical factor influencing the ice nuclei concentration number (e.g., Phillips et al., 2008; DeMott et al., 2010) and determines the distribution of clouds, radiation, and precipitation (Zhao et al., 2013a). By comparing the dust particle number loading from three different approaches of representing dust size distribution (8-bin, 4-bin, and 3-mode), Zhao et al. (2013b) pointed out that the 8-bin approach could better represent the dust particle number distribution for different sizes. In this study, we use the MOSAIC aerosol scheme with the 8-bin approach to simulate the long-range transport of dust particles. Figure 10b shows the vertical distribution of the number of dust particles vs. particle size from 0.039 to $10.0 \mu \mathrm{m}$ over the TP. It suggests that dust particle number has a similar seasonal variability as the dust mass vs. dust particle size. However, the size range is different for dust from various sources over the TP. The East Asian and North African dust particle numbers are predominately in the range of 0.156-1.25 $\mu \mathrm{m}$, but the Middle Eastern dust particle numbers fall in a broader range of $0.078-2.5 \mu \mathrm{m}$. Compared with the dust mass, the dust particle number loading over the TP is mainly smaller in particle size. This is likely due to the easier suspension and long-range transport of smaller dust particles (Chin et al., 2007). The East Asian dust particle number concentration over the TP is mainly at $2-8 \mathrm{~km}$ with a peak $\left(\sim 0.4 \mathrm{~mm}^{-3}\right)$ in MAM and has a smaller dust particle number concentration compared with other sources. While the North African and Middle Eastern dust particle number concentration have a broader vertical distribution, even reaching up to $12 \mathrm{~km}$. For the number of Middle Eastern dust particles, there is a significant peak value occurring (more than $1 \mathrm{~mm}^{-3}$ ) below $4 \mathrm{~km}$, which is larger than other sources. This result implies that the dust from the Middle East could contribute more particles to the number of dust particles, which could influence regional clouds and precipitation.

Figure 11 shows the spatial distribution of dust particle number loading between $0-3,3-6,6-9$, and 9-12 km. Clearly, the dust particle number concentration reduces from west to east, but the gradient is smaller than that of dust mass due to a faster removal rate of mass in general (Zhao et al., 2013b). Between 0-3 km, the greatest number of dust particles appear over the source regions (i.e., the Sahara, Arabian, Thar, Gobi, and Taklamakan deserts) with a value of $0.08 \mu \mathrm{m}^{-2}$. Between 3-6 km, dust particle number loading reduces, and a value of $\sim 0.008 \mu \mathrm{m}^{-2}$ appears over the TP. The dust particle number loading increases $\left(\sim 0.02 \mu \mathrm{m}^{-2}\right)$ due to the orographic effect, which is consistent with the dust AOD distribution at $6-9 \mathrm{~km}$ (Fig. 3). At $9-12 \mathrm{~km}$, there is a peak in the number of dust particles over the north of the TP with a value of $\sim 0.008 \mu \mathrm{m}^{-2}$. 

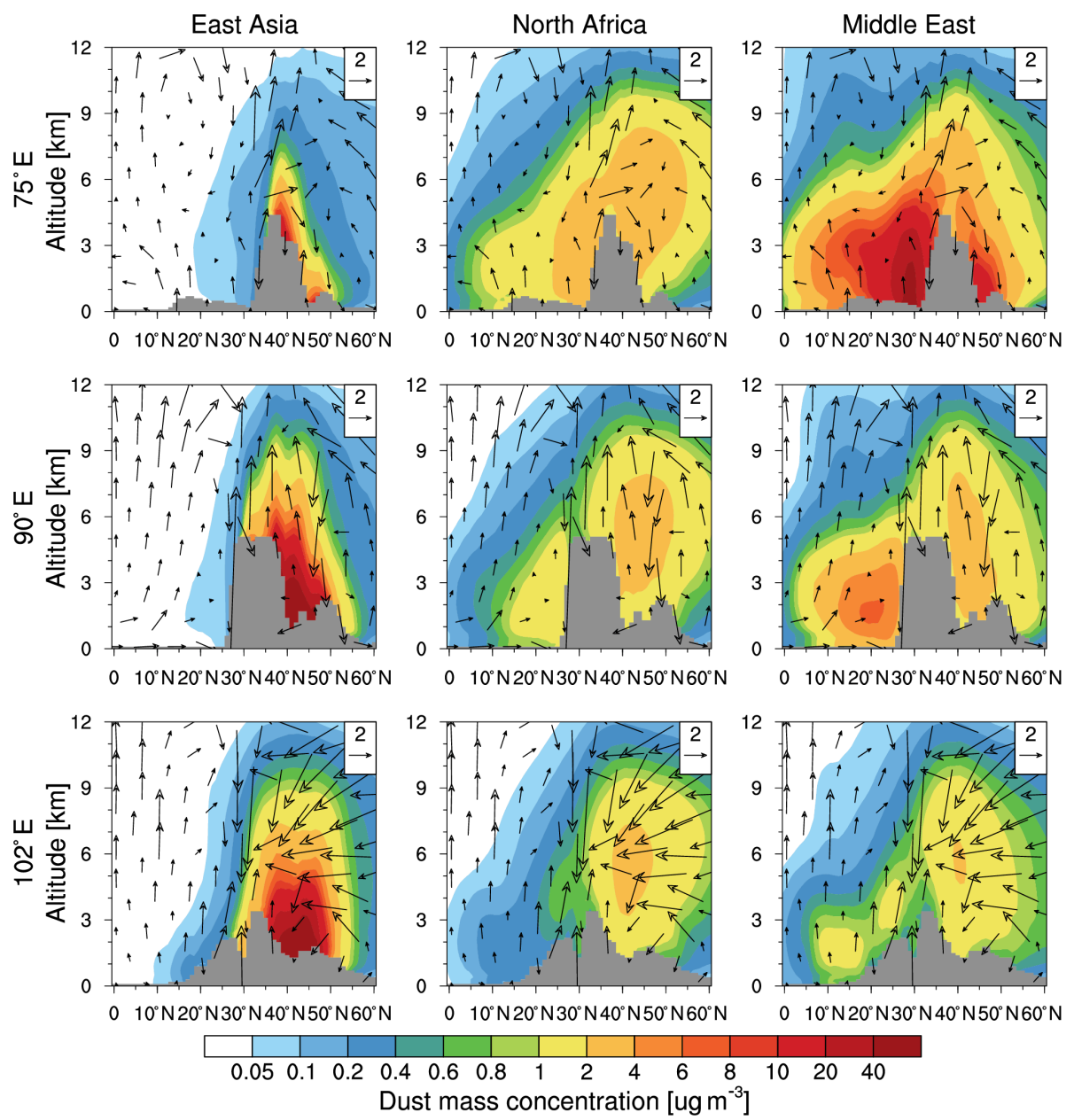

Figure 6. Vertical cross sections of meridional circulation (in meters per second and a scale factor of 300 is applied for vertical wind) and zonal dust mass concentration (in micrograms per cubic meter) emitted from East Asia, North Africa, and the Middle East at 75, 90, and $102^{\circ} \mathrm{E}$.

\subsection{Dust radiative forcing over the TP}

Figure 12 shows the spatial distribution of annual mean SW, $\mathrm{LW}$, and net $(\mathrm{SW}+\mathrm{LW})$ direct radiative forcing of dust at the TOA, in the atmosphere (ATM) and at the surface (SFC) from the WRF-Chem simulations averaged over 2010-2015. Over the TP, the dust SW radiative forcing is negative at TOA with a value around $-0.5 \mathrm{~W} \mathrm{~m}^{-2}$, which is far less than the value over the desert regions due to the high dust albedo and absorbing capability (Zhao et al., 2011). Because of dust LW absorption, the dust LW radiative forcing at TOA is warming with a positive value of $0.5 \mathrm{~W} \mathrm{~m}^{-2}$. Overall, the net dust radiative forcing at TOA has a cooling effect. In the atmosphere, the dust warms the atmosphere through absorbing SW and cools the atmosphere by increasing atmospheric outgoing LW radiation. Dust produces a net warming effect with a value of $0.5 \mathrm{~W} \mathrm{~m}^{-2}$ over the TP. At the surface, the dust induces a cooling effect by reducing downward SW radiation and a warming effect by trapping the LW radiation emit- ted from surface. Moreover, the net dust radiative forcing is negative and cooling the surface. The seasonal and annual mean SW, LW, and net radiative forcing of dust simulated by WRF-Chem over the TP are summarized in Fig. 13. The dust significantly cools the TOA and SFC and warms the atmosphere with a peak effect in MAM, because of a larger dust mass concentration in this season over the TP (Hu et al., 2019a). Also, the annual dust-related SW radiation forcing values are $-1.40 \mathrm{~W} \mathrm{~m}^{-2}$ (TOA), $0.67 \mathrm{~W} \mathrm{~m}^{-2}$ (ATM), and $-2.08 \mathrm{~W} \mathrm{~m}^{-2}$ (SFC), which is far larger than the dust-related $\mathrm{LW}$ radiation forcing values, which are $0.13 \mathrm{~W} \mathrm{~m}^{-2}$ (TOA), $-0.26 \mathrm{~W} \mathrm{~m}^{-2}$ (ATM), and $0.39 \mathrm{~W} \mathrm{~m}^{-2}$ (SFC). Overall, the dust-induced change in net radiation forcing is $-1.28 \mathrm{~W} \mathrm{~m}^{-2}$ at the TOA, $0.41 \mathrm{~W} \mathrm{~m}^{-2}$ in the ATM, and $-1.68 \mathrm{~W} \mathrm{~m}^{-2}$ at the SFC over the TP. The annual mean radiative effect of dust is less than in the results from Chen et al. (2013), which investigated the dust radiative forcing under an intense dust storm event. 

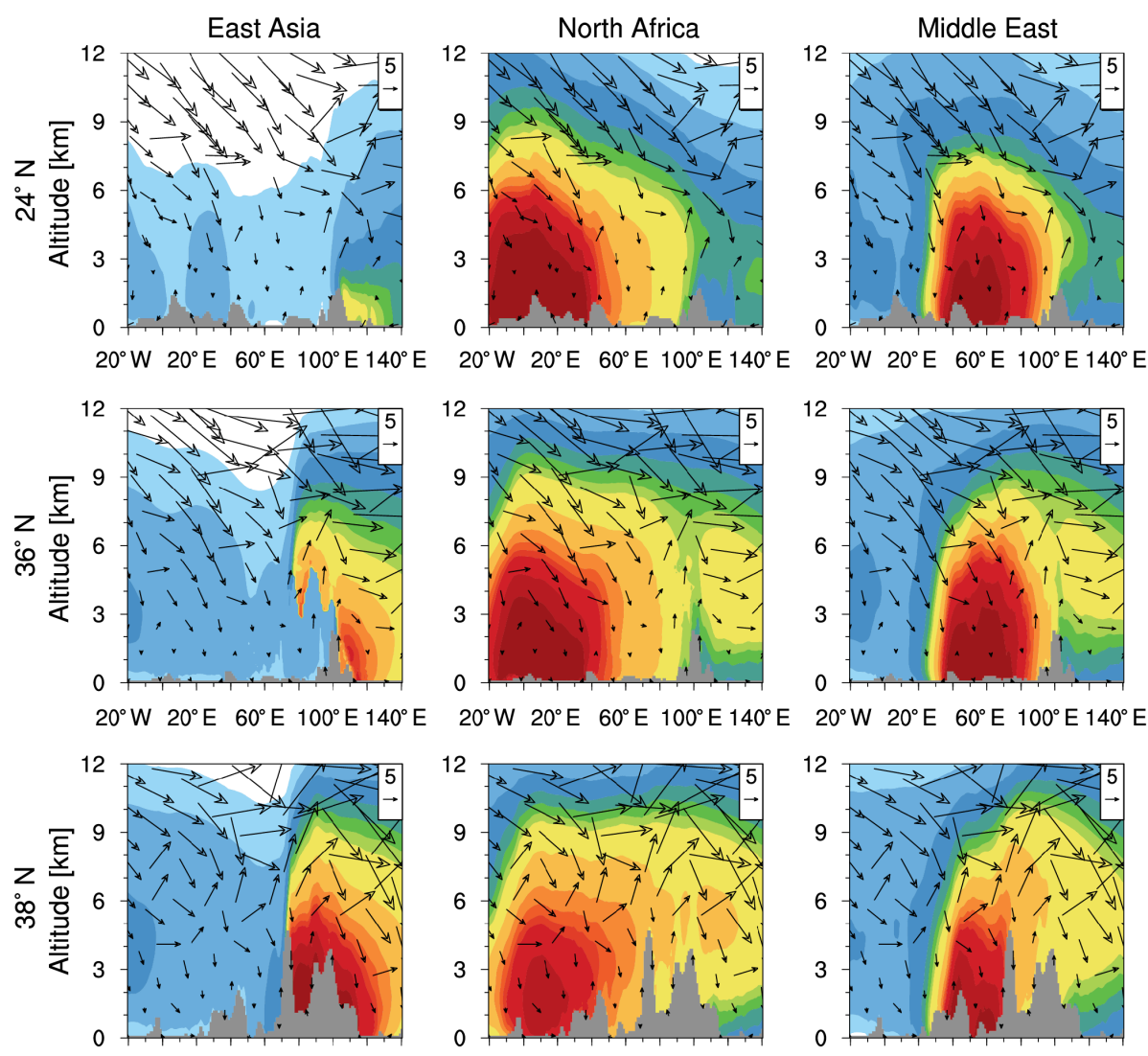

$20^{\circ} \mathrm{W} 20^{\circ} \mathrm{E} 60^{\circ} \mathrm{E} 100^{\circ} \mathrm{E} 140^{\circ} \mathrm{E}$

$20^{\circ} \mathrm{W} 20^{\circ} \mathrm{E} \quad 60^{\circ} \mathrm{E} 100^{\circ} \mathrm{E} 140^{\circ} \mathrm{E} \quad 20^{\circ} \mathrm{W} 20^{\circ} \mathrm{E} \quad 60^{\circ} \mathrm{E} 100^{\circ} \mathrm{E} 140^{\circ} \mathrm{E} \quad 20^{\circ} \mathrm{W} \quad 20^{\circ} \mathrm{E} \quad 60^{\circ} \mathrm{E} 100^{\circ} \mathrm{E} 140^{\circ} \mathrm{E}$

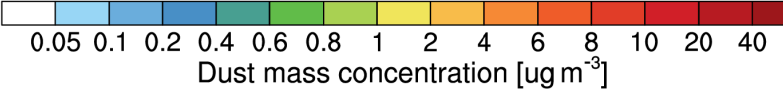

Figure 7. Vertical cross sections of zonal circulation (in meters per second and a scale factor of 300 applied for vertical wind) and meridional dust mass concentration (in micrograms per cubic meter) emitted from East Asia, North Africa, and the Middle East at 24,36 , and $38^{\circ} \mathrm{N}$.

\subsection{Comparison between dust and other aerosols at different altitudes over the TP}

Figure 14 shows the vertical distribution of seasonal AOD, aerosol mass, and aerosol particle number over the TP. Significantly, AOD, aerosol mass, and aerosol particle number decrease with altitude. At $0-3 \mathrm{~km}$, the peak AOD $(0.24)$ is in JJA, but the peak aerosol mass $\left(88 \mu \mathrm{g} \mathrm{m}^{-2}\right)$ and aerosol particle number $\left(7.2 \mu \mathrm{m}^{-2}\right)$ are in MAM. While, above $6 \mathrm{~km}$, the effect of aerosols has a peak in MAM. Also, the aerosol mass and particle number have a larger decrease from the surface to $6 \mathrm{~km}$. At $6-12 \mathrm{~km}$, weaker decreasing indicates that dust and sulfate, in particular, decrease less with altitude and account for more than $50 \%$ of the total aerosols (Fig. 15). At higher altitudes $(9-12 \mathrm{~km})$ there are no obvious seasonal changes in the aerosols.

In order to explore the relative contribution of dust, the fraction from dust and other components is shown in Fig. 15. Clearly, the fraction of dust AOD shows an increasing trend with altitude. The fraction of dust AOD has significant seasonal variabilities at different altitudes with a peak in MAM.
For aerosol mass, the dust fraction is more than $50 \%$ in MAM $(57 \%)$ and JJA (65\%) due to the maximum intercontinental transport of dust into the TP at $0-3 \mathrm{~km}$. Above $3 \mathrm{~km}$, the dust mass contribution fraction is more than $55 \%$. The maximum contribution value occurs at $6-9 \mathrm{~km}$ in all seasons, except JJA (occurs at 3-6 km). However, the number of dust particles contributed can be ignored. The major portions of the aerosol particle number are sulfate, OM, and other aerosols. The sulfate particle number contribution increases with the altitude, but the OM decreases. At $0-3 \mathrm{~km}$, OM contributes the greatest amount, with a value of more than $40 \%$. At 3-9 km, other aerosols contribute about $40 \%$ to the number of particles. At $9-12 \mathrm{~km}$, sulfate contributes more than $45 \%$ to the number of particles.

\section{Conclusions and discussion}

In this study, we conduct a quasi-global WRF-Chem simulation and implement a newly developed tracer-tagging method, which divides the global deserts into four source 

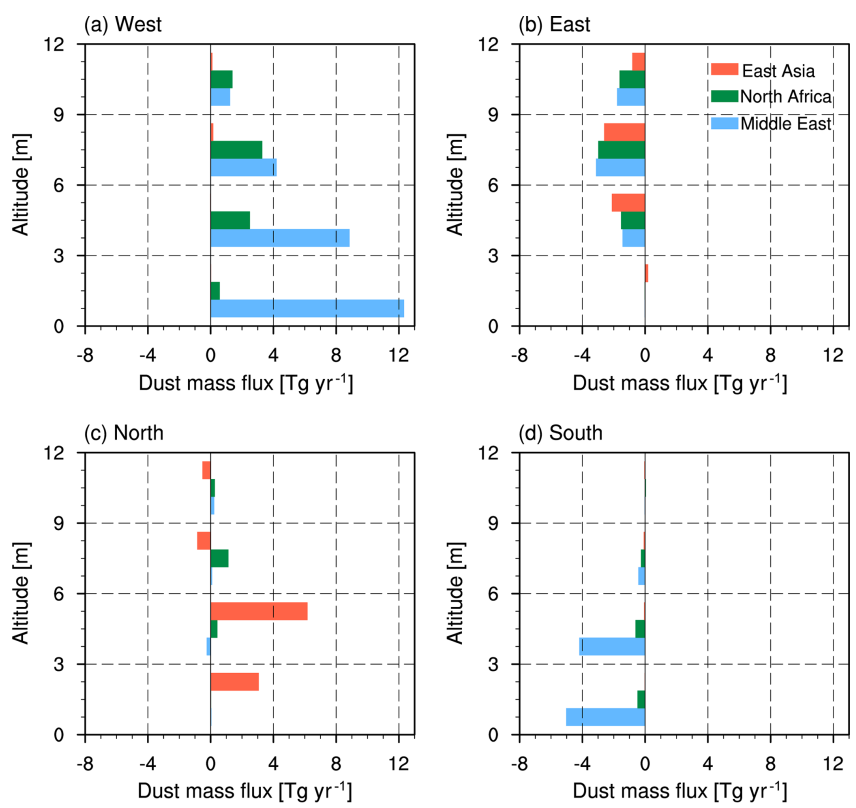

Figure 8. Model-based estimation of annual dust mass flux (in teragrams per year) at the (a) west, (b) east, (c) north, and (d) south sides of the Tibetan Plateau. The latitude ranges from 27 to $38^{\circ} \mathrm{N}$, and the longitude ranges from 75 to $104^{\circ} \mathrm{E}$. The west and east mass flux carried into the TP are based on the zonal wind, and the south and north mass flux are based on the meridional wind. Also, the values are positive for dust carried in and negative for dust flowing out.
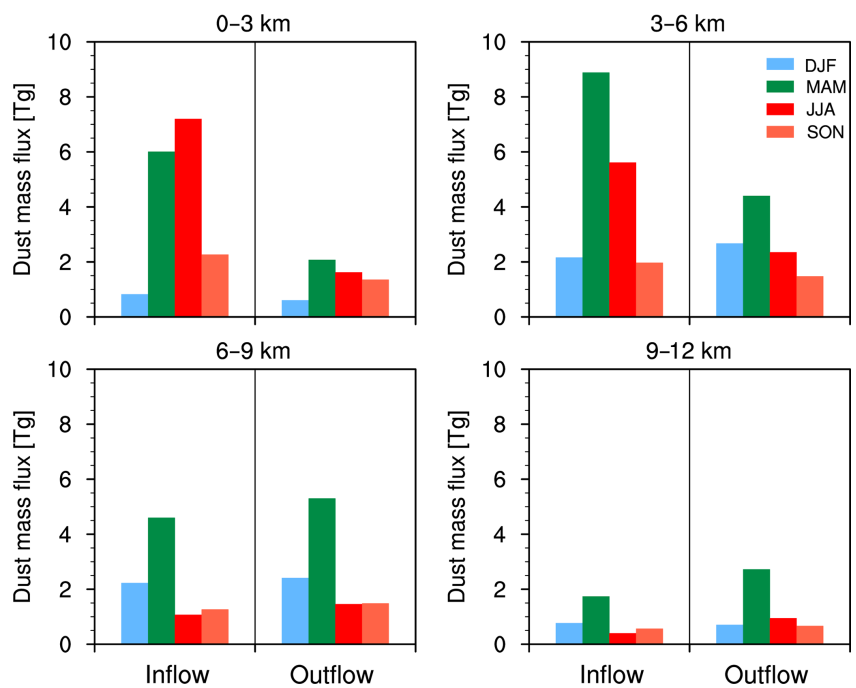

Figure 9. Model-based estimation of annual dust mass flux (teragrams) inflow and outflow from the TP between 0-3, 3-6, 6-9, and 9-12 km from the WRF-Chem simulations averaged over 20102015.
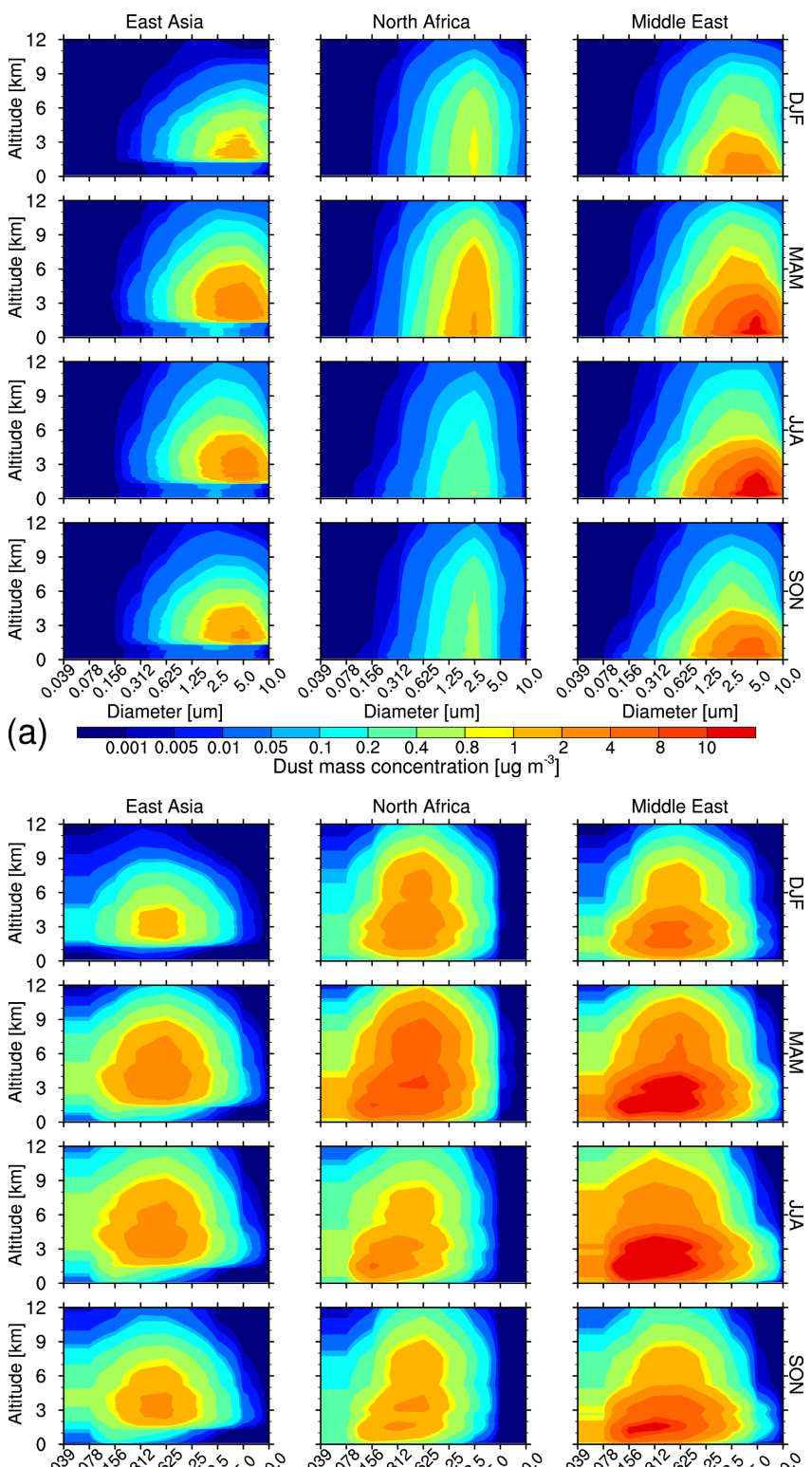

(b)

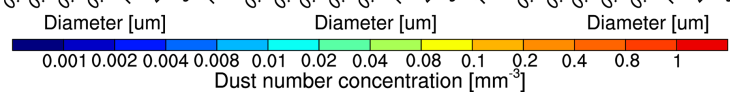

Figure 10. (a) Vertical distribution of seasonal dust mass concentration (micrograms per cubic meter) over the TP within various particle size groups emitted from East Asia, North Africa, and the Middle East averaged for 2010-2015. (b) Vertical distribution of seasonal dust particle number concentration (per cubic meter) over the TP in different particle sizes emitted from East Asia, North Africa, and the Middle East averaged over the period of 2010-2015. 

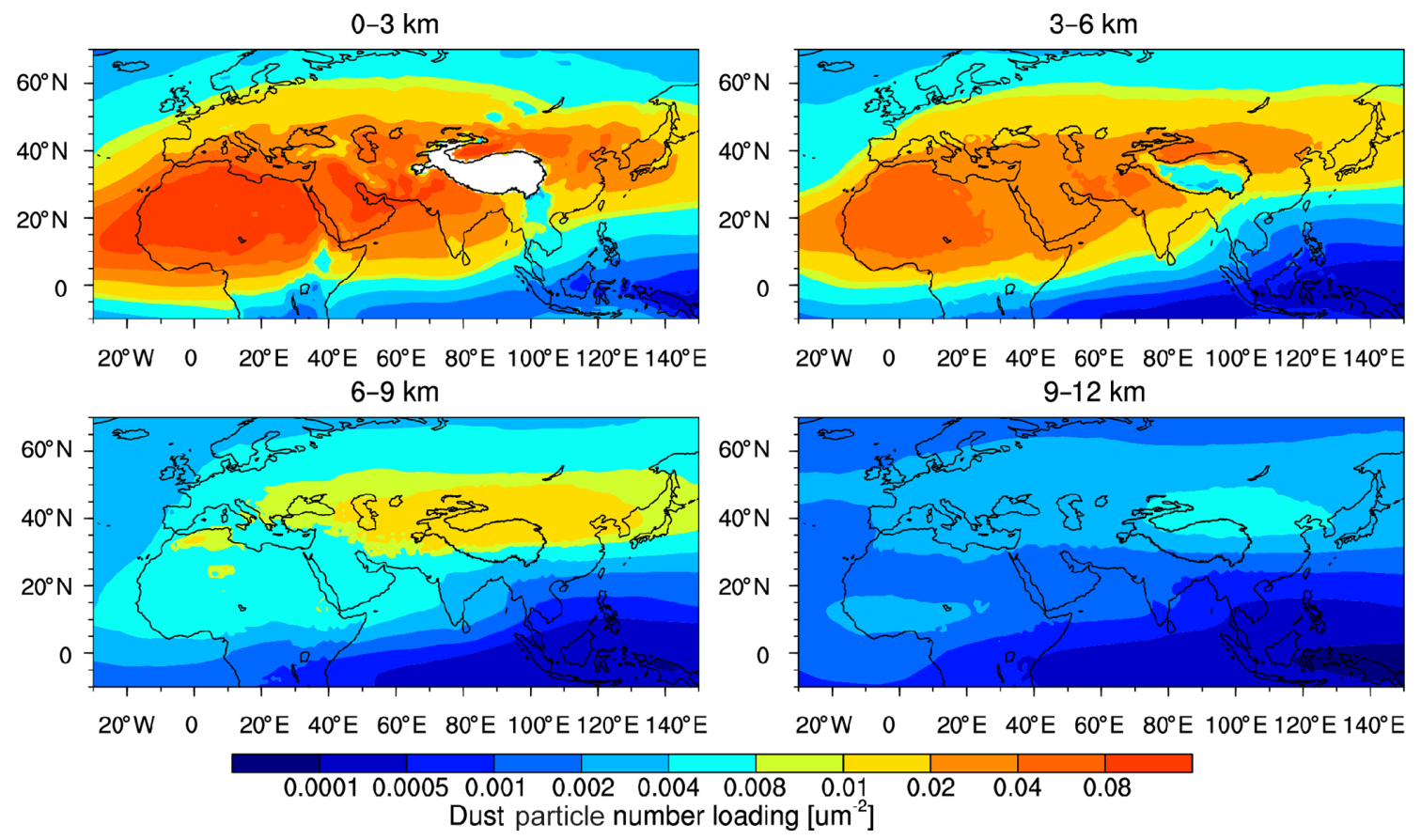

Figure 11. Spatial distributions of annual mean dust particle number loading (per square micrometer) from WRF-Chem between 0-3, 3-6, 6-9, and 9-12 km for the period of 2010-2015.

regions and explicitly online, tracks the emission, transport, and deposition of the dust particles. Using this method, we investigate dust source, intercontinental transport, and radiative forcing at the different altitudes over the TP for the period of 2010-2015. The main conclusions are summarized below:

1. The spatial and seasonal variability in AOD can be captured well by the model simulation. Observation and simulated results show that the maximum AOD appeared over North Africa, the Middle East, and central Asia in JJA but in MAM over East Asia. Also, the model has a reliable representation of spatial distribution of dust AOD at different altitudes when compared with the CALIPSO retrievals. The maximum dust AOD appears around the dust sources, with a peak value of 0.6.

2. Lifted by updrafts, dust particles are emitted into the atmosphere over the major desert regions and then transport to downwind regions. The East Asian dust is transported southward and rises up to the TP over the northern slope with the mass loading from 50 (at $3 \mathrm{~km}$ ) to 5 (at $12 \mathrm{~km}$ ) $\mathrm{mg} \mathrm{m}^{-2}$. The North African dust is transported eastward under the westerly wind, mixes with the Middle Eastern dust and then is carried into East Asia. However, the TP stands in the way and splits the dust plumes into two branches. The North African dust is carried into the TP over the northern slope with a mass of $10 \mathrm{mg} \mathrm{m}^{-2}$ below $6 \mathrm{~km}$. While the Middle Eastern dust concentrates over the southern slope with a dust mass loading of $\sim 50 \mathrm{mg} \mathrm{m}^{-2}$ below $6 \mathrm{~km}$ and passes over the TP with mass loading of $5-10 \mathrm{mg} \mathrm{m}^{-2}$ above $6 \mathrm{~km}$. Overall, East Asia contributes more dust mass over the northern slope, and the Middle East contributes more dust mass over the southern slope. At higher altitudes (above $6 \mathrm{~km}$ ) over the TP, the major contributor is from the Middle East with a value of $60 \%$.

3. On an annual basis, the Middle Eastern dust and North African dust are mainly carried into the TP on the west side with mass fluxes of 26.6 and $7.8 \mathrm{Tg} \mathrm{yr}^{-1}$, while the East Asian dust is carried into the TP on north side with a mass flux of $8.0 \mathrm{Tg} \mathrm{yr}^{-1}$. The mass fluxes of different source dust flowing out of the TP from the east and south sides are -5.4 (East Asia), -6.2 (North Africa), and -6.4 (the Middle East) $\mathrm{Tg} \mathrm{yr}^{-1}$ and -0.2 (East Asia), -1.3 (North Africa), and -9.7 (the Middle East) $\mathrm{Tg} \mathrm{yr}^{-1}$, respectively. The greatest dust mass flux carried into and flowing out from the TP is at $3-6 \mathrm{~km}$. Also, the incoming and out flowing dust mass fluxes mainly occur in MAM. The peak values are $8.9 \mathrm{Tg}$ (inflow) and $4.4 \mathrm{Tg}$ (outflow) at $3-6 \mathrm{~km}$ and $6.4 \mathrm{Tg}$ (inflow) and $8.0 \mathrm{Tg}$ (outflow) above $6 \mathrm{~km}$.

4. The dust can be brought up to $9 \mathrm{~km}$ under the effect of the TP orography. Inside, the East Asian dust mass dominates in the size range of $1.25-10.0 \mu \mathrm{m}$ in spring (MAM), followed by JJA. While, the North African and Middle Eastern dust masses are mainly in the range of $1.25-5.0 \mu \mathrm{m}$, and the dust particles can reach heights 

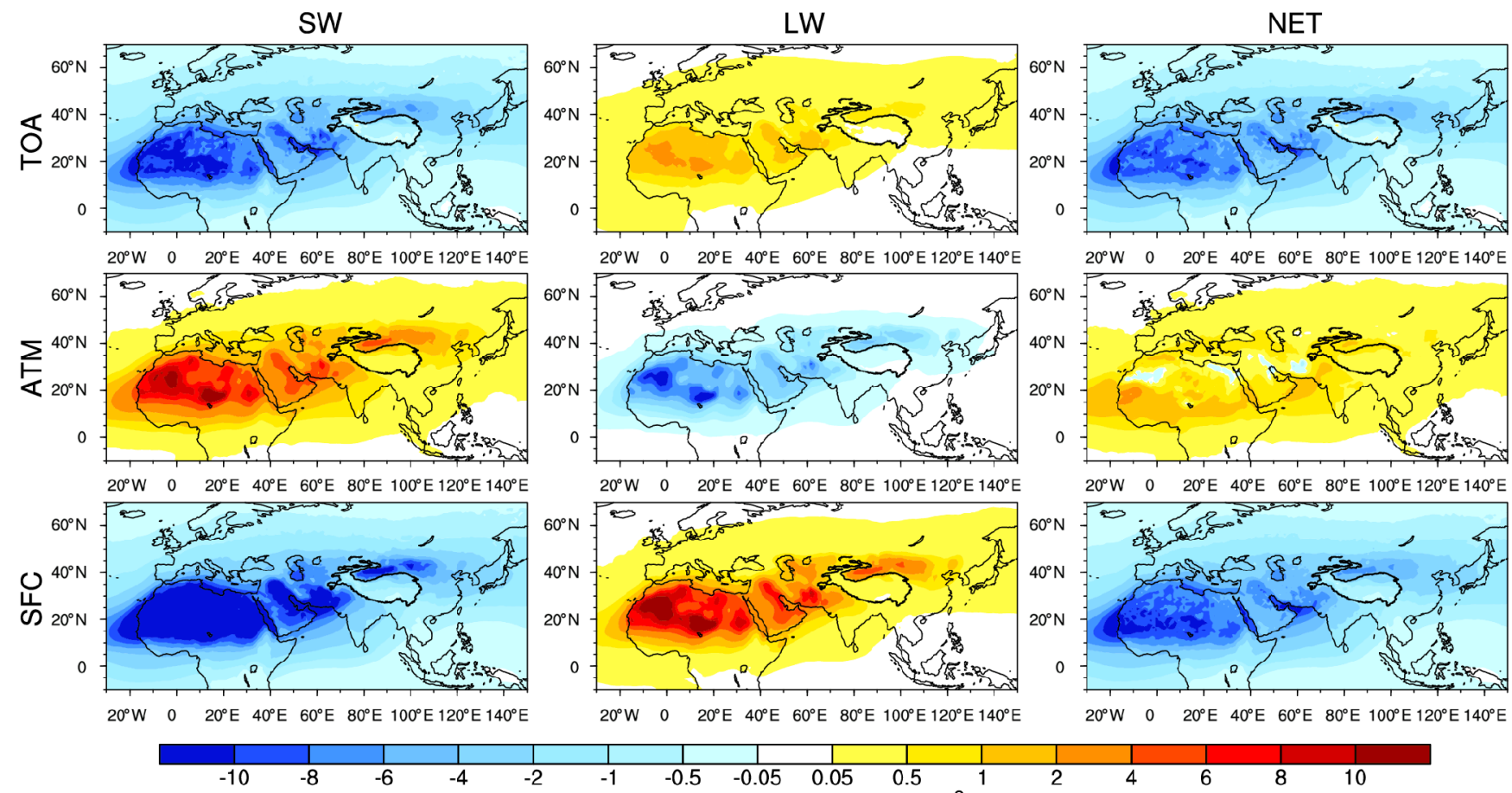

$20^{\circ} \mathrm{W} \quad 0 \quad 20^{\circ} \mathrm{E} \quad 40^{\circ} \mathrm{E} \quad 60^{\circ} \mathrm{E} \quad 80^{\circ} \mathrm{E} 100^{\circ} \mathrm{E} 120^{\circ} \mathrm{E} 140^{\circ} \mathrm{E}$

$20^{\circ} \mathrm{W} \quad 2 \quad 20^{\circ} \mathrm{E} \quad 40^{\circ} \mathrm{E} \quad 60^{\circ} \mathrm{E} \quad 80^{\circ} \mathrm{E} 100^{\circ} \mathrm{E} 120^{\circ} \mathrm{E} 140^{\circ} \mathrm{E}$

Dust radiative forcing $\left[\mathrm{W} \mathrm{m}^{-2}\right]$

Figure 12. Spatial distribution of annual mean SW, LW, and net (SW $+\mathrm{LW}$ ) direct radiative forcing (watts per square meter) of dust at the TOA (top panels), in the atmosphere (ATM: middle panels), and at the surface (SFC: bottom panels) under all sky conditions from the WRF-Chem simulation averaged over 2010-2015.
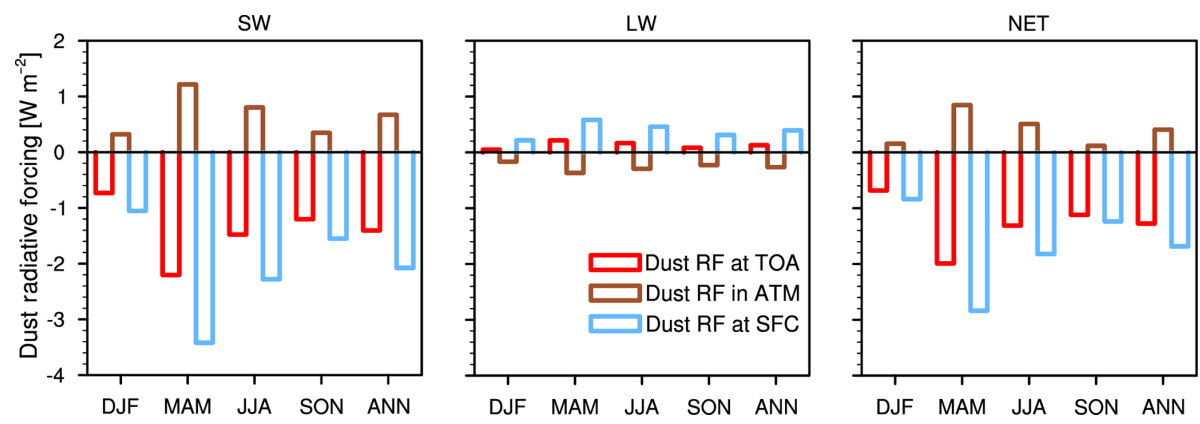

Figure 13. Seasonal and annual mean SW, LW, and net (SW + LW) radiative forcing (watts per square meter) of dust simulated by WRFChem for the period of 2010-2015 over the TP. Negative values represent downward radiation.

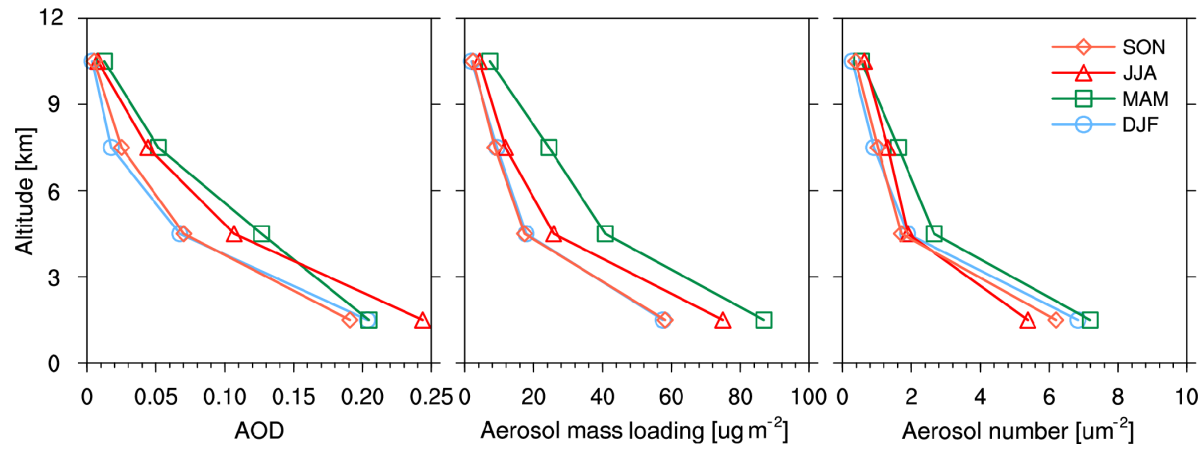

Figure 14. Vertical distribution of seasonal AOD, aerosol mass loading (micrograms per square meter), and aerosol number (particles per square micrometer) over the TP from the WRF-Chem simulation averaged over the period of 2010-2015. 


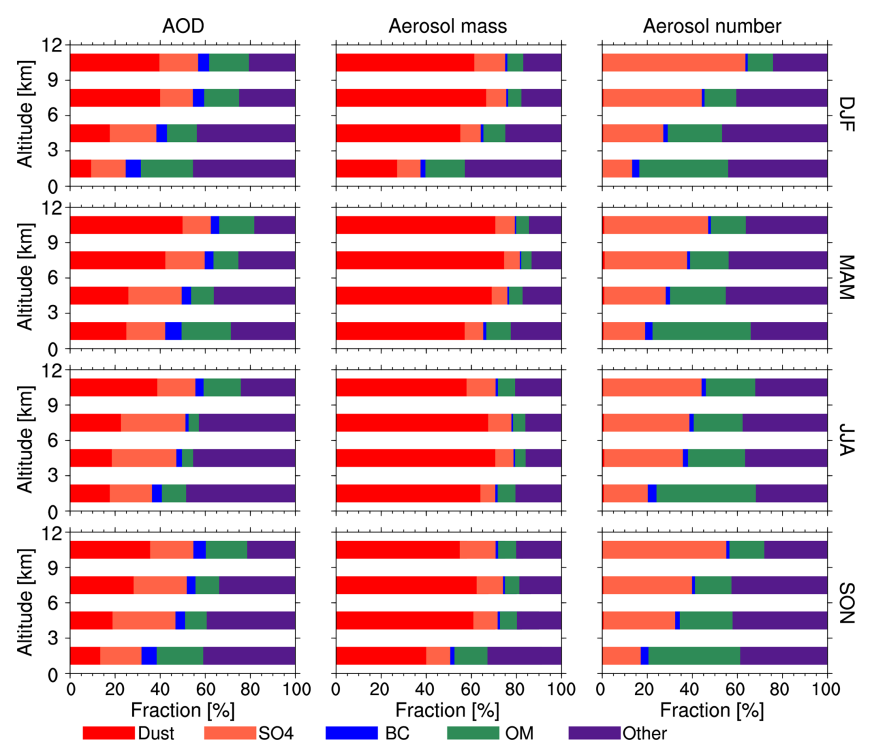

Figure 15. Fractions of seasonal aerosol composition in total AOD (left), aerosol mass concentration (middle), and aerosol number (right) in four separate vertical layers: 0-3, 3-6, 6-9, and 9-12 km from the WRF-Chem simulation averaged for the period of 20102015 over the TP.

up to $12 \mathrm{~km}$, but the Middle Eastern dust contributes a larger fraction to the total dust mass. For the dust particle number, the East Asian and North African dust are predominately in the range of $0.156-1.25 \mu \mathrm{m}$, but the Middle Eastern dust particle number falls in 0.078$2.5 \mu \mathrm{m}$. Relatively, the East Asian dust particles over the TP are mainly at $2-8 \mathrm{~km}$, while the North African and Middle Eastern dust particles are broader, even reaching to $12 \mathrm{~km}$.

5. For the radiative forcing, dust produces the annual mean $\mathrm{SW}, \mathrm{LW}$, and net $(\mathrm{SW}+\mathrm{LW})$ radiation forcing of $-1.40,0.13$, and $-1.27 \mathrm{~W} \mathrm{~m}^{-2}$ at the TOA, 0.67, -0.26 , and $0.41 \mathrm{~W} \mathrm{~m}^{-2}$ in the atmosphere, and -2.08 , 0.39 , and $-1.69 \mathrm{~W} \mathrm{~m}^{-2}$ at the surface over the TP, respectively. For the aerosol mass, the dust contribution accounts for more than $50 \%$ in MAM (57\%) and JJA $(65 \%)$ due to the maximum intercontinental transport of dust into the TP at $0-3 \mathrm{~km}$. Above $3 \mathrm{~km}$, the dust mass contribution accounts for more than $55 \%$ with a peak contribution at $6-9 \mathrm{~km}$. However, there is a smaller contribution of total aerosols from dust particles compared with sulfate, OM, and other aerosol particles in the column. For the aerosol optical characteristics, the fraction of dust AOD follows an increasing trend with altitude, while the total dust AOD is decreasing with altitude.

The WRF-Chem quasi-global simulation not only captures the spatial and seasonal variabilities of the long-range transport of dust but also tags the dust particle loading into the TP from different major deserts over North America, East
Asia, North Africa, and the elsewhere in the world (mainly in the Middle East). The dust from the Gobi and Taklimakan deserts is transported southward and is lifted up to the TP at northern slope. While dust from North Africa and the Middle East is transported eastward and then lifts up to the TP at both the northern and southern slopes. Under the effect of TP and strong Indian summer monsoon, the dust particles can reach the upper troposphere (above $8 \mathrm{~km}$ ) and even lower stratosphere. This study proposes a pathway for dust transport into the upper troposphere and provides a climatological view about the intercontinental transport characteristics of dust from different source regions over the TP. Also, this study explores the dust particle size and number distribution over the TP, and shows that the number of dust particles has a smaller contribution to the total number of aerosols compared with sulfate, OM, and other anthropogenic aerosols in the column. Our results are important for understanding the source contribution of the dust over TP and the dust belt formation over the Northern Hemisphere. However, the impact of dust aerosols on cloud properties and precipitation and the diabatic heating of dust over the TP are not discussed, which will be investigated in future studies.

Code availability. The release version 3.5.1 of WRF-Chem can be download from http://www2.mmm.ucar.edu/wrf/users/ download/get_source.html (WRF Users Page, 2020). The updated model is available by contacting the first author (huzhiyuan@mail.sysu.edu.cn). Also, the code modifications will be incorporated in the release version of WRF-Chem.

Supplement. The supplement related to this article is available online at: https://doi.org/10.5194/acp-20-1507-2020-supplement.

Author contributions. $\mathrm{ZH}$ and $\mathrm{CZ}$ conducted the quasi-global simulations. $\mathrm{ZH}$ performed the analyses, wrote the paper, and coordinated the paper. All authors contributed to the final version of the paper.

Competing interests. The authors declare that they have no conflict of interest.

Special issue statement. This article is part of the special issue "Study of ozone, aerosols and radiation over the Tibetan Plateau (SOAR-TP) (ACP/AMT inter-journal SI)". It is not associated with a conference.

Acknowledgements. We thank to the University of Science and Technology of China (USTC) for providing the updated version of Weather Research and Forecasting model with chemistry (WRFChem). We also thank the editor Tao Wang and three anonymous 
referees for their insight and invaluable suggestions that improved this paper.

Financial support. This research was supported by the Foundation for Innovative Research Groups of the National Natural Science Foundation of China (grant No. 41521004), the National Natural Science Foundation of China (grant nos. 41805116, 41905013, and 41775146), the Strategic Priority Research Program of Chinese Academy of Sciences (grant no. XDA2006010301), and the Fundamental Research Funds for the Central Universities (grant nos. lzujbky-2019-pd05, lzujbky-2018-49, lzujbky-2019-kb02, and lzujbky-2019-kb31).

Review statement. This paper was edited by Tao Wang and reviewed by three anonymous referees.

\section{References}

Alizadeh-Choobari, O., Sturman, A., and Zawar-Reza, P.: A global satellite view of the seasonal distribution of mineral dust and its correlation with atmospheric circulation, Dynam. Atmos. Oceans, 68, 20-34, 2014.

Ben-Ami, Y., Koren, I., Altaratz, O., Kostinski, A., and Lehahn, Y.: Discernible rhythm in the spatio/temporal distributions of transatlantic dust, Atmos. Chem. Phys., 12, 2253-2262, https://doi.org/10.5194/acp-12-2253-2012, 2012.

Bi, J., Huang, J., Shi, J., Hu, Z., Zhou, T., Zhang, G., Huang, Z., Wang, X., and Jin, H.: Measurement of scattering and absorption properties of dust aerosol in a Gobi farmland region of northwestern China - a potential anthropogenic influence, Atmos. Chem. Phys., 17, 7775-7792, https://doi.org/10.5194/acp17-7775-2017, 2017.

Binkowski, F. S. and Shankar, U.: The Regional Particulate Matter Model 1. Model description and preliminary results, J. Geophys. Res., 100, 26191-26209, 1995.

Bourgeois, Q., Ekman, A. M. L., and Krejci, R.: Aerosol transport over the Andes from the Amazon Basin to the remote Pacific Ocean: A multiyear CALIOP assessment, J. Geophys. Res.-Atmos., 120, 8411-8425, https://doi.org/10.1002/2015JD023254, 2015.

Chapman, E. G., Gustafson Jr., W. I., Easter, R. C., Barnard, J. C., Ghan, S. J., Pekour, M. S., and Fast, J. D.: Coupling aerosol-cloud-radiative processes in the WRF-Chem model: Investigating the radiative impact of elevated point sources, Atmos. Chem. Phys., 9, 945-964, https://doi.org/10.5194/acp-9945-2009, 2009.

Chen, S., Huang, J., Zhao, C., Qian, Y., Leung, L. R., and Yang, B.: Modeling the transport and radiative forcing of Taklimakan dust over the Tibetan Plateau: A case study in the summer of 2006, J. Geophys. Res.-Atmos., 118, 797-812, https://doi.org/10.1002/jgrd.50122, 2013.

Chen, S., Huang, J., Kang, L., Wang, H., Ma, X., He, Y., Yuan, T., Yang, B., Huang, Z., and Zhang, G.: Emission, transport, and radiative effects of mineral dust from the Taklimakan and Gobi deserts: comparison of measurements and model results, At- mos. Chem. Phys., 17, 2401-2421, https://doi.org/10.5194/acp17-2401-2017, 2017.

Chen, S., Jiang, N., Huang, J., Xu, X., Zhang, H., Zang, Z., Huang, K., Xu, X., Wei, Y., Guan, X., Zhang, X., Luo, Y., Hu, Z., and Feng, T.: Quantifying contributions of natural and anthropogenic dust emission from different climatic regions, Atmos. Environ. 191, 94-104, 2018.

Chin, M., Diehl, T., Ginoux, P., and Malm, W.: Intercontinental transport of pollution and dust aerosols: implications for regional air quality, Atmos. Chem. Phys., 7, 5501-5517, https://doi.org/10.5194/acp-7-5501-2007, 2007.

DeMott, P., Prenni, A., Liu, X., Kreidenweis, S., Petters, M., Twohy, C., Richardson, M., Eidhammer, T., and Rogers, D.: Predicting global atmospheric ice nuclei distributions and their impacts on climate, P. Natl. Acad. Sci. USA, 107, 11217-11222, 2010.

Dentener, F., Kinne, S., Bond, T., Boucher, O., Cofala, J., Generoso, S., Ginoux, P., Gong, S., Hoelzemann, J. J., Ito, A., Marelli, L., Penner, J. E., Putaud, J.-P., Textor, C., Schulz, M., van der Werf, G. R., and Wilson, J.: Emissions of primary aerosol and precursor gases in the years 2000 and 1750 prescribed data-sets for AeroCom, Atmos. Chem. Phys., 6, 43214344, https://doi.org/10.5194/acp-6-4321-2006, 2006.

D’Errico, M., Cagnazzo, C., Fogli, P. G., Lau, K. M., von Hardenberg, J., Fierli, F., and Cherchi, A.: Indian monsoon and the elevated-heat-pump mechanism in a coupled aerosolclimate model, J. Geophys. Res.-Atmos., 120, 8712-8723, https://doi.org/10.1002/2015JD023346, 2015.

Diner, D. J., Beckert, J. C., Reilly, T. H., Bruegge, C. J., Conel, J. E., Kahn, R. A., Martonchik, J. V., Ackerman, T. P., Davies, R., Gerstl, S. A. W., Gordon, H. R., Muller, J. P., Myneni, R. B., Sellers, P. J., Pinty, B., and Verstraete, M. M.: Multi-angle Imaging SpectroRadiometer (MISR) Instrument Description and Experiment Overview, IEEE T. Geosci. Remote, 36, 1072-1087, 1998.

Duan, A. M. and Wu, G. X.: Weakening trend in the atmospheric heat source over the Tibetan Plateau during recent decades. Part I: Observations, J. Climate, 21, 3149-3164, https://doi.org/10.1175/2007JCLI1912.1, 2008.

Duan, A., Wu, G., Zhang, Q., and Liu, Y.: New proofs of the recent climate warming over the Tibetan Plateau as a result of the increasing greenhouse gases emissions, Chinese Sci. Bull., 51, 1396-1400, https://doi.org/10.1007/s11434-006-1396-6, 2006.

Easter, R. C., Ghan, S. J., Zhang, Y., Saylor, R. D., Chapman, E. G., Laulainen, N. S., Abdul-Razzak, H., Leung, L. R., Bian, X., and Zaveri, R. A.: MIRAGE: Model Description and Evaluation of Aerosols and Trace Gases, J. Geophys. Res., 109, D20210, https://doi.org/10.1029/2004JD004571, 2004.

Fast, J. D., Gustafson, W. I., Easter, R. C., Zaveri, R. A., Barnard, J. C., Chapman, E. G., Grell, G. A., and Peckham, S. E.: Evolution of ozone, particulates, and aerosol direct radiative forcing in the vicinity of Houston using a fully coupled meteorology chemistry-aerosol model, J. Geophys. Res., 111, D21305, https://doi.org/10.1029/2005JD006721, 2006.

Ginoux, P., Chin, M., Tegen, I., Prospero, J. M., Holben, B., Dubovik, O., and Lin, S. J.: Sources and distributions of dust aerosols simulated with the GOCART model, J. Geophys. Res., 106, 20255-20273, 2001. 
Gong, S. L.: A parameterization of sea-salt aerosol source function for sub- and super-micron particles, Global Biogeochem. Cy., 17, 1097, https://doi.org/10.1029/2003GB002079, 2003.

Hsu, N. C., Tsay, S. C., King, M. D., and Herman, J. R.: Deep Blue Retrievals of Asian Aerosol Properties During ACE-Asia, IEEE T. Geosci. Remote, 44, 3180-3195, 2006.

Hsu, N. C., Jeong, M.-J., and Bettenhausen, C.: Enhanced Deep Blue aerosol retrieval algorithm: The second generation, J. Geophys. Res.-Atmos., 118, 9296-9315, 2013.

Hu, Z., Zhao, C., Huang, J., Leung, L. R., Qian, Y., Yu, H., Huang, L., and Kalashnikova, O. V.: Trans-Pacific transport and evolution of aerosols: evaluation of quasi-global WRF-Chem simulation with multiple observations, Geosci. Model Dev., 9, 17251746, https://doi.org/10.5194/gmd-9-1725-2016, 2016.

Hu, Z., Huang, J., Zhao, C., Bi, J., Jin, Q., Qian, Y., Leung, L. R., Feng, T., Chen, S., and Ma, J.: Modeling the contributions of Northern Hemisphere dust sources to dust outflow from East Asia, Atmos. Environ., 202, 234-243, 2019a.

Hu, Z., Huang, J., Zhao, C., Ma, Y., Jin, Q., Qian, Y., Leung, L. R., Bi, J., and Ma, J.: Trans-Pacific transport and evolution of aerosols: spatiotemporal characteristics and source contributions, Atmos. Chem. Phys., 19, 12709-12730, https://doi.org/10.5194/acp-19-12709-2019, 2019 b.

Huang, J., Minnis, P., Lin, B., Yi, Y., Khaiyer, M. M., Arduini, R. F., Fan, A., and Mace, G. G.: Advanced retrievals of multilayered cloud properties using multispectral measurements, J. Geophys. Res., 110, D15S18, https://doi.org/10.1029/2004JD005101, 2005.

Huang, J., Lin, B., Minnis, P., Wang, T., Wang, X., Hu, Y., Yi, Y., and Ayers, J.: Satellite-based assessment of possible dust aerosols semi-direct effect on cloud water path over East Asia, Geophys. Res. Lett., 33, L19802, https://doi.org/10.1029/2006GL026561, 2006.

Huang, J., Minnis, P., Yi, Y., Tang, Q., Wang, X., Hu, Y., Liu, Z., Ayers, K., Trepte, C., and Winker, D.: Summer dust aerosols detected from CALIPSO over the Tibetan Plateau, Geophys. Res. Lett., 34, L18805, https://doi.org/10.1029/2007GL029938, 2007.

Huang, J., Minnis, P., Chen, B., Huang, Z., Liu, Z., Zhao, Q., Yi, Y., and Ayers, J.: Long-range transport and vertical structure of Asian dust from CALIPSO and surface measurements during PACDEX, J. Geophys. Res., 113, D23212, https://doi.org/10.1029/2008JD010620, 2008.

Huang, J., Fu, Q., Zhang, W., Wang, X., Zhang, R., Ye, H., and Warren, S.: Dust and black carbon in seasonal snow across northern China, B. Am. Meteorol. Soc., 92, 175-181, https://doi.org/10.1175/2010BAMS3064.1, 2011.

Huang, J., Wang, T., Wang, W., Li, Z., and Yan, H.: Climate effects of dust aerosols over East Asian arid and semiarid regions, J. Geophys. Res.-Atmos., 119, 11398-11416, https://doi.org/10.1002/2014JD021796, 2014.

Iacono, M. J., Mlawer, E. J., Clough, S. A., and Morcrette, J. J.: Impact of an improved longwave radiation model, RRTM, on the energy budget and thermodynamic properties of the NCAR community climate model, CCM3, J. Geophys. Res., 105, 1487314890, 2000.

Jaeglé, L., Quinn, P. K., Bates, T. S., Alexander, B., and Lin, J.-T.: Global distribution of sea salt aerosols: new constraints from in situ and remote sensing observations, Atmos. Chem. Phys., 11, 3137-3157, https://doi.org/10.5194/acp-11-3137-2011, 2011.
Janssens-Maenhout, G., Crippa, M., Guizzardi, D., Dentener, F., Muntean, M., Pouliot, G., Keating, T., Zhang, Q., Kurokawa, J., Wankmüller, R., Denier van der Gon, H., Kuenen, J. J. P., Klimont, Z., Frost, G., Darras, S., Koffi, B., and Li, M.: HTAP_v2.2: a mosaic of regional and global emission grid maps for 2008 and 2010 to study hemispheric transport of air pollution, Atmos. Chem. Phys., 15, 11411-11432, https://doi.org/10.5194/acp-15-11411-2015, 2015.

Jin, Q. and Wang, Q.: A revival of Indian summer monsoon rainfall since 2002, Nat. Clim. Change, 7, 587-594, 2017.

Jin, Q., Wei, J., and Yang, Z.-L.: Positive response of Indian summer rainfall to Middle East dust, Geophys. Res. Lett., 41, 4068-4074, https://doi.org/10.1002/2014GL059980, 2014.

Jin, Q., Wei, J., Yang, Z.-L., Pu, B., and Huang, J.: Consistent response of Indian summer monsoon to Middle East dust in observations and simulations, Atmos. Chem. Phys., 15, 9897-9915, https://doi.org/10.5194/acp-15-9897-2015, 2015.

Jin, Q., Yang, Z.-L., and Wei, J.: Seasonal Responses of Indian Summer Monsoon to Dust Aerosols in the Middle East, India, and China, J. Climate, 29, 6329-6349, https://doi.org/10.1175/jcli-d-15-0622.1, 2016.

Kang, S., Wake, C., Qin, D., Mayewski, P. A., and Yao, T.: Monsoon and dust signals recorded in Dasuopu glacier, Tibetan Plateau, J. Glaciol., 46, 222-226, 2000.

Kang, S., Wei, X., You, Q., Flugel, W., Pepin, N., and Yao, T.: Review of climate and cryospheric change in the Tibetan Plateau, Environ. Res. Lett., 5, 015101, https://doi.org/10.1088/17489326/5/1/015101, 2010.

Kaufman, Y. J., Tanré, D., Remer, L. A., Vermote, E. F., Chu, A., and Holben, B. N.: Operational remote sensing of tropospheric aerosol over land from EOS moderate resolution imaging spectroradiometer, J. Geophys. Res., 102, 17051-17067, 1997.

Kim, M. K., Lau, K. M., Kim, M. K., Sang, J., Kim, Y., and Lee, W.: Amplification of ENSO effects on Indian summer monsoon by absorbing aerosols, Clim. Dynam., 49, 1945-1960, 2017.

Lau, K. M. and Kim, M. K.: Observational relationships between aerosol and Asian monsoon rainfall, and circulation, Geophys. Res. Lett., 33, L21810, https://doi.org/10.1029/2006GL027546, 2006.

Lau, K. M., Kim, M. K., and Kim, K. M.: Asian summer monsoon anomalies induced by aerosol direct forcing: the role of the Tibetan Plateau, Clim. Dynam., 26, 855-864, 2006.

Lau, K. M., Kim, M. K., Kim, K.-M., and Lee, W. S.: Enhanced surface warming and accelerated snow melt in the Himalayas and Tibetan Plateau induced by absorbing aerosols, Environ. Res. Lett., 5, 025204, https://doi.org/10.1088/1748-9326/5/2/025204, 2010.

Lau, K. M., Kim, M. K., Shi, J., Matsui T., Chin, M., Tan, Q., PetersLidard, C., and Tao, W. K.: Impacts of aerosol-monsoon interaction on rainfall and circulation over Northern India and the Himalaya Foothills, Clim. Dynam., 49, 1945-1960, 2016.

Lee, Y., Yang, X., and Wenig, M.: Transport of dusts from East Asian and non-East Asian sources to Hong Kong during dust storm related events 1996-2007, Atmos. Environ., 44, 37283738, 2010.

Levy, R. C., Mattoo, S., Munchak, L. A., Remer, L. A., Sayer, A. M., Patadia, F., and Hsu, N. C.: The Collection 6 MODIS aerosol products over land and ocean, Atmos. Meas. Tech., 6, 29893034, https://doi.org/10.5194/amt-6-2989-2013, 2013. 
Li, J., Lv, Q., Zhang, M., Wang, T., Kawamoto, K., Chen, S., and Zhang, B.: Effects of atmospheric dynamics and aerosols on the fraction of supercooled water clouds, Atmos. Chem. Phys., 17, 1847-1863, https://doi.org/10.5194/acp-17-1847-2017, 2017.

Li, J., Jian, B., Huang, J., Hu, Y., Zhao, C., Kawamoto, K., Liao, $\mathrm{S}$., and $\mathrm{Wu}, \mathrm{M}$.: Long-term variation of cloud droplet number concentrations from space-based Lidar, Remote Sens. Environ., 213, 144-161, doi.org/10.1016/j.rse.2018.05.011, 2018.

Li, Z., Lau, W. K., Ramanathan, V., Wu, G., Ding, Y., Manoj, M. G., Liu, J., Qian, Y., Li, J., Zhou, T., Fan., J., Rosenfeld, D., Ming, Y., Wang, Y., Huang, J., Wang, B., Xu, X., Lee, S.-S., Cribb, M., Zhang, F., Yang, X., Zhao, C., Takemura, T., Wang, K., Xia, X., Yin, Y., Zhang, H., Guo, J., Zhao, P., Sugimoto, N., Babu, S. S., and Brasseur, G. P.: Aerosol and monsoon climate interactions over Asia, Rev. Geophys., 54, 866-929, 2016.

Liu, X. and Penner, J. E.: Ice nucleation parameterization for global models, Meteorol. Z., 14, 499-514, 2005.

Liu, X., Xie, X., Yin, Z.-Y., Liu, C., and Gettelman, A.: A modeling study of the effects of aerosols on clouds and precipitation over East Asia, Theor. Appl. Climatol., 106, 343-354, 2011.

Liu, Y., Sato, Y., Jia, R., Xie, Y., Huang, J., and Nakajima, T.: Modeling study on the transport of summer dust and anthropogenic aerosols over the Tibetan Plateau, Atmos. Chem. Phys., 15, 12581-12594, https://doi.org/10.5194/acp-15-125812015, 2015.

Liu, Z., Omar, A., Vaughan, M., Vaughan, M., Hair, J., Kittaka, C., Hu, Y., Powell, K., Trepte, C., Winker, D., Hostetler, C., Ferrare, R., and Pierce, R.: CALIPSO lidar observations of the optical properties of Saharan dust: A case study of long-range transport, J. Geophys. Res., 113, D07207, https://doi.org/10.1029/2007JD008878, 2008.

Ma, Y., Zhong, L., Wang, B., Ma, W., Chen, X., and Li, M.: Determination of land surface heat fluxes over heterogeneous landscape of the Tibetan Plateau by using the MODIS and in situ data, Atmos. Chem. Phys., 11, 10461-10469, https://doi.org/10.5194/acp-11-10461-2011, 2011.

Ma, Y., Zhu, Z., Zhong, L., Wang, B., Han, C., Wang, Z., Wang, Y., Lu, L., Amatya, P. M., Ma, W., and Hu, Z.: Combining MODIS, AVHRR and in situ data for evapotranspiration estimation over heterogeneous landscape of the Tibetan Plateau, Atmos. Chem. Phys., 14, 1507-1515, https://doi.org/10.5194/acp14-1507-2014, 2014.

Mahowald, N., Jickells, T. D., Baker, A. R., Artaxo, P., BenitezNelson, C. R., Bergametti, G., Bond, T. C., Chen, Y., Cohen, D. D., Herut, B., Kubilay, N., Losno, R., Luo, C., Maenhaut, W., McGee, K. A., Okin, G. S., Siefert, R. L., and Tsukuda, S.: The global distribution of atmospheric phosphorus deposition and anthropogenic impacts, Global Biogeochem. Cy., 22, GB4026, https://doi.org/10.1029/2008GB003240, 2008.

Mao, R., Hu, Z., Zhao, C., Gong, D., Guo, D., and Wu, G.: The source contributions to the dust over the Tibetan Plateau: A modelling analysis, Atmos. Environ., 214, 13522310, https://doi.org/10.1016/j.atmosenv.2019.116859, 2019.

Martonchik, J. V., David, J. D., Crean, K. A., and Bull, M. A.: Regional Aerosol Retrieval Results From MISR, IEEE T. Geosci. Remote, 40, 1520-1531, 2002.

Middleton, N. J.: A geography of dust stroms in southwest Asia, J. Climate, 6, 183-196, 1986.
Mlawer, E. J., Taubman, S. J., Brown, P. D., Iacono, M. J., and Clough, S. A.: Radiative transfer for inhomogeneous atmospheres: RRTM, a validated correlated- $k$ model for the longwave, J. Geophys. Res., 102, 16663-16682, 1997.

Nigam, S. and Bollasina, M.: "Elevated heat pump" hypothesis for the aerosol-monsoon hydroclimate link: "Grounded" in observations?, J. Geophys. Res., 115, D16201, https://doi.org/10.1029/2009JD013800, 2010.

Nowottnick, E., Colarco, P., da Silva, A., Hlavka, D., and McGill, M.: The fate of saharan dust across the atlantic and implications for a central american dust barrier, Atmos. Chem. Phys., 11, 8415-8431, https://doi.org/10.5194/acp-11-8415-2011, 2011.

Painter, T. H., Deems, J. S., Belnap, J., Hamlet, A. F., Landry, C. C., and Udall, B.: Response of Colorado River runoff to dust radiative forcing in snow, P. Natl. Acad. Sci. USA, 107, 1712517130, https://doi.org/10.1073/pnas.0913139107, 2010.

Park, C., Sugimoto, N., Matsui, I., Shimizu, A., Tatarov, B., Kamei, A., Lee, C., Uno, I., Takemura, T., Westphal, D. L.: Long-range Transport of Saharan Dust to East Asia Observed with Lidars, SOLA, 1, 121-124, 2005.

Phillips, V., DeMott, P., and Andronache, C.: An empirical parameterization of heterogeneous ice nucleation for multiple chemical species of aerosol, J. Atmos. Sci., 65, 2757-2783, 2008.

$\mathrm{Pu}, \mathrm{B}$. and Ginoux, P.: How reliable are CMIP5 models in simulating dust optical depth?, Atmos. Chem. Phys., 18, 12491-12510, https://doi.org/10.5194/acp-18-12491-2018, 2018.

Qian, Y., Gustafson, W. I., Leung, L. R., and Ghan, S. J.: Effects of soot-induced snow albedo change on snowpack and hydrological cycle in western United States basedon Weather Research and Forecasting chemistryand regional climate simulations, J. Geophys. Res., 114, D03108, https://doi.org/10.1029/2008JD011039, 2009.

Remer, L. A., Kaufman, Y. J., Tanre, D., Mattoo, S., Chu, D. A., Martins, J. V., Li, R. R., Ichoku, C., Levy, R. C., Kleidman, R. G., Eck, T. F., Vermote, E., and Holben, B. N.: The MODIS aerosol algorithm, products and validation, J. Atmos. Sci., 62, 947-973, 2005.

Ren, J., Jing, Z., Pu, J., and Qin, X.: Glaciers variations and climate change in the central Himalaya over the past few decades, Ann. Glaciol., 43, 218-222, 2006.

Sayer, A. M., Munchak, L. A., Hsu, N. C., Levy, R. C., Bettenhausen, C., and Jeong, M.-J.: MODIS Collection 6 aerosol products: Comparison between Aqua's e-Deep Blue, Dark Target, and "merged" data sets, and usage recommendations, J. Geophys. Res.-Atmos., 119, 13965-13989, https://doi.org/10.1002/2014JD022453, 2014.

Stauffer, D. R. and Seaman, N. L.: Use of Four-Dimensional Data Assimilation in a Limited_Area Mesoscale Model. Part I: Experiments with Synoptic-Scale Data, Mon. Weather Rev., 118, 1250-1277, 1990.

Su, L. and Toon, O. B.: Saharan and Asian dust: similarities and differences determined by CALIPSO, AERONET, and a coupled climate-aerosol microphysical model, Atmos. Chem. Phys., 11, 3263-3280, https://doi.org/10.5194/acp-11-3263-2011, 2011.

Uno, I., Satake, S., Carmichael, G. R., Tang, Y., Wang, Z., Takemura, T., Sugimoto, N., Shimizu, A., Murayama, T., Cahill, T. A., Cliff, S., Uematsu, M., Ohta, S., Quinn, P. K., and Bates, T. S.: Numerical study of Asian dust transport during the springtime of 2001 simulated with the Chemical Weather Forecast- 
ing System (CFORS) model, J. Geophys. Res., 109, D19S24, https://doi.org/10.1029/2003JD004222, 2004.

Uno, I., Eguchi, K., Yumimoto, K., Takemura, T., Shimizu, A., Uematsu, M., Liu, Z., Wang, Z., Hara, Y., and Sugimoto, N.: Asian dust transported one full circuit around the globe, Nat. Geosci., 2, 557-560, https://doi.org/10.1038/ngeo583, 2009.

Wang, B., Bao, Q., Hoskins, B.,Wu, G., and Liu, Y.: Tibetan Plateau warming and precipitation changes in East Asia, Geophys. Res. Lett., 35, L14702, https://doi.org/10.1029/2008GL034330, 2008.

Wang, H., Rasch, P. J., Easter, R. C., Singh, B., Zhang, R., Ma, P. L., Qian, Y., and Beagley, N.: Using an explicit emission tagging method in global modeling of source-receptor relationships for black carbon in the Arctic: Variations, Sources and Transport pathways, J. Geophys. Res.-Atmos., 119, 12888-12909, https://doi.org/10.1002/2014JD022297, 2014.

Watson, J. G.: Visibility: Science and regulation, J. Air Waste Manage., 52, 628-713, 2002.

Wiedinmyer, C., Akagi, S. K., Yokelson, R. J., Emmons, L. K., AlSaadi, J. A., Orlando, J. J., and Soja, A. J.: The Fire INventory from NCAR (FINN): a high resolution global model to estimate the emissions from open burning, Geosci. Model Dev., 4, 625641, https://doi.org/10.5194/gmd-4-625-2011, 2011.

Winker, D. M., Hunt, W. H., and McGill, M. J.: Initial performance assessment of CALIOP, Geophys. Res. Lett., 34, L19803, https://doi.org/10.1029/2007GL030135, 2007.

Winker, D. M., Vaughan, M. A., Omar, A., Hu, Y., Powell, K. A., Liu, Z., Hunt, W. H., and Young, S. A.: Overview of the CALIPSO Mission and CALIOP Data Processing Algorithms, J. Atmos. Ocean. Tech., 26, 2310-2323, https://doi.org/10.1175/2009JTECHA1281.1, 2009.

Winker, D. M., Pelon, J., Coakley, A. J., Ackerman, S. A., Charlson, R. J., Colarco, P. R., Flamant, P., Fu, Q., Hoff, R. M., Kittaka, C., Kubar, T. L., Treut, H. L., Mccormick, M. P., Mégie, G., Poole, L., Powell, K., Trepte, C., Vaughan, M. A., and Wielicki, B. A.: The CALIPSO mission: a global 3D view of aerosols and clouds, B. Am. Meteorol. Soc., 91, 1211-1229, 2010.

Witek, M. L., Garay, M. J., Diner, D. J., Bull, M. A., and Seidel, F. C.: New approach to the retrieval of AOD and its uncertainty from MISR observations over dark water, Atmos. Meas. Tech., 11, 429-439, https://doi.org/10.5194/amt-11-429-2018, 2018.

WRF Users Page: WRF downloads, available at: https://www2. mmm.ucar.edu/wrf/users/downloads.html, last access: 31 January 2020.

Wu, G., Liu, Y., Zhang, Q., and Duan, A.: The influence of mechanical and thermal forcing by the Tibetan Plateau on Asian climate, J. Hydrometeorol., 8, 770-789, 2007.

Wu, G., Liu, Y., He, B., Bao, Q., Duan, A., and Jin, F.-F.: Thermal controls on the Asian summer monsoon, Sci. Rep.-UK, 2, 404, https://doi.org/10.1038/srep00404, 2012.

Xu, B., Cao, J., Hansen, J., Yao, T., Joswiak, D. R., Wang, N., Wu, G., Wang, M., Zhao, H., Yang, W., Liu, X., and He, J.: Black soot and the survival of Tibetan glaciers, P. Natl. Acad. Sci. USA, 106, 22114-22118, 2009.

Xu, C., Ma, Y., Yang, K., and You, C.: Tibetan Plateau Impacts on Global Dust Transport in the Upper Troposphere, J. Climate, 31, 4745-4756, 2018.

Yao, T., Pu, J., Lu, A., Wang, Y., and Yu, W.: Recent glacial retreat and its impact on hydrological processes on the Tibetan Plateau,
China, and surrounding regions, Arct. Antarct. Alp. Res., 39, 642-650, 2007.

Yao, T., Thompson, L., Yang, W., Yu, W., Gao, Y., Guo, X., Yang, X., Duan, K., Zhao, H., Xu, B., Pu, J., Lu, A., Xiang, Y., Kattel, D. B., and Joswiak, D.: Different glacier status with atmospheric circulations in Tibetan Plateau and surroundings, Nat. Clim. Change, 2, 663-667, https://doi.org/10.1038/nclimate1580, 2012.

Ye, D. and Wu, G.: The role of the heat source of the Tibetan Plateau in the general circulation, Meteorol. Atmos. Phys., 67, 181-198, https://doi.org/10.1007/BF01277509, 1998.

Yeh, T., Lo, S., and Chu, P.: The wind structure and heat balance in the lower troposphere over Tibetan Plateau and its surrounding, Acta Meteor. Sinica, 28, 108-121, 1957.

Yu, H., Remer, L. A., Chin, M., Bian, H. S., Kleidman, R. G., and Diehl, T.: A satellite-based assessment of transpacific transport of pollution aerosol, J. Geophys. Res., 113, D14S12, https://doi.org/10.1029/2007JD009349, 2008.

Yu, H., Chin, M., Winker, D., Omar, A., Liu, Z., Kittaka, C., and Diehl, T.: Global view of aerosol vertical distributions from CALIPSO lidar measurements and GOCART simulations: Regional and seasonal variations, J. Geophys. Res., 115, D00H30, https://doi.org/10.1029/2009JD013364, 2010.

Yu, H., Remer, L. A., Chin, M., Bian, H., Tan, Q., Yuan, T., and Zhang, Y.: Aerosols from Overseas Rival Domestic Emissions over North America, Science, 337, 566-569, 2012.

Yu, H., Remer, L. A., Kahn, R. A., Chin, M., and Zhang Y.: Satellite perspective of aerosol intercontinental transport: From qualitative tracking to quantitative characterization, Atmos. Res., 124, 73-100, https://doi.org/10.1016/j.atmosres.2012.12.013, 2013.

Yu, H., Chin, M., Bian, H., Yuan, T. L., Prospero, J. M., Omar, A. H., Remer, L. A., Winker, D. M., Yang, Y., Zhang, Y., and Zhang, Z.: Quantification of trans-Atlantic dust transport from seven-year (2007-2013) record of CALIPSO lidar measurements, Remote Sens. Environ., 159, 232-249, https://doi.org/10.1016/j.rse.2014.12.010, 2015.

Yumimoto, K., Eguchi, K., Uno, I., Takemura, T., Liu, Z., Shimizu, A., and Sugimoto, N.: An elevated large-scale dust veil from the Taklimakan Desert: Intercontinental transport and three-dimensional structure as captured by CALIPSO and regional and global models, Atmos. Chem. Phys., 9, 8545-8558, https://doi.org/10.5194/acp-9-8545-2009, 2009.

Yumimoto, K., Eguchi, K., Uno, I., Takemura, T., Liu, Z., Shimizu, A., Sugimoto, N., and Strawbridge, K.: Summertime transPacific transport of Asian dust, Geophys. Res. Lett., 37, L18815, https://doi.org/10.1029/2010GL043995, 2010.

Zaveri, R. A. and Peters, L. K.: A new lumped structure photochemical mechanism for large-scale applications, J. Geophys. Res., 104, 30387-30415, 1999.

Zaveri, R. A., Easter, R. C., Fast, J. D., and Peters, L. K.: Model for Simulating Aerosol Interactions and Chemistry (MOSAIC), J. Geophys. Res., 113, D13204, https://doi.org/10.1029/2007JD008782, 2008.

Zhao, C., Liu, X., Leung, L. R., Johnson, B., McFarlane, S. A., Gustafson Jr., W. I., Fast, J. D., and Easter, R.: The spatial distribution of mineral dust and its shortwave radiative forcing over North Africa: modeling sensitivities to dust emissions and aerosol size treatments, Atmos. Chem. Phys., 10, 8821-8838, https://doi.org/10.5194/acp-10-8821-2010, 2010. 
Zhao, C., Liu, X., Ruby Leung, L., and Hagos, S.: Radiative impact of mineral dust on monsoon precipitation variability over West Africa, Atmos. Chem. Phys., 11, 1879-1893, https://doi.org/10.5194/acp-11-1879-2011, 2011.

Zhao, C., Leung, L. R., Easter, R., Hand, J., and Avise, J.: Characterization of speciated aerosol direct radiative forcing over California, J. Geophys. Res., 118, 2372-2388, https://doi.org/10.1029/2012JD018364, 2013a.

Zhao, C., Chen, S., Leung, L. R., Qian, Y., Kok, J. F., Zaveri, R. A., and Huang, J.: Uncertainty in modeling dust mass balance and radiative forcing from size parameterization, Atmos. Chem. Phys., 13, 10733-10753, https://doi.org/10.5194/acp-13-107332013, 2013b.
Zhao, C., Hu, Z., Qian, Y., Ruby Leung, L., Huang, J., Huang, M., Jin, J., Flanner, M. G., Zhang, R., Wang, H., Yan, H., Lu, Z., and Streets, D. G.: Simulating black carbon and dust and their radiative forcing in seasonal snow: a case study over North China with field campaign measurements, Atmos. Chem. Phys., 14, 1147511491, https://doi.org/10.5194/acp-14-11475-2014, 2014.

Zhao, T. L., Gong, S. L., Zhang, X. Y., Blanchet, J. P., McKendry, I. G., and Zhou, Z. J.: A simulated climatology of Asian dust aerosol and its trans-Pacific transport, Part I: Mean climate and validation, J. Climate, 19, 88-103, 2006. 